\title{
Race and language teaching
}

\author{
Kerry Soo Von Esch ${ }^{1 *}$, Suhanthie Motha ${ }^{2}$ and Ryuko Kubota ${ }^{3}$ \\ ${ }^{1}$ College of Education, Seattle University, Seattle, USA, ${ }^{2}$ Department of English, University of Washington, Seattle, USA and \\ ${ }^{3}$ Department of Language and Literacy Education, University of British Columbia, Vancouver, Canada \\ ${ }^{\star}$ Corresponding author. Email: voneschk@seattleu.edu
}

\begin{abstract}
In this review article on race and language teaching, we highlight an urgent need for the international educational community to continue to develop a complex understanding of how language teaching and learners' lives are shaped by our global history of racist practices of colonial expansion, including settler colonialism and transatlantic slavery. We outline the genesis of research on race and language teaching and review literature that reflects a recent increase in scope and range of studies that problematize the workings of race and racism in language teaching and point to hopeful solutions for addressing effects of racial inequities. We conceptualize two key terms, 'race' and 'language,' then overview theories that appeared most significant in the research literature. We explore five interconnected themes that featured prominently throughout the existing literature on race and language teaching: standard language ideology and racial hegemony, the idealized and racialized native speaker, racial hierarchies of languages and language speakers, racialization and teacher identity, and race-centered approaches to pedagogies and educational practices. We offer a critical analysis of the current status of scholarship on race and language teaching, including gaps and necessary reframing, and conclude with implications for future directions and questions arising from the work.
\end{abstract}

\section{Introduction}

While scholarship explicitly connecting race to the language teaching profession began to emerge notably only in recent decades, the racialization of language teaching has a history that is likely as old as language teaching itself. For many centuries, even millennia, language contact and transmission have frequently taken place between communities and individuals of different racial identifications. The ways languages have been shared, withheld, or forced upon learners have played an important role in shaping related power inequities and racial formations and in mobilizing different material and social resources. Moreover, with language functioning as a 'technology of erasure through cultural assimilation' (Glenn, 2015, p. 68), particularly over the past few centuries, a great deal of language teaching and learning in the global context has been shaped by the violent, strategically maneuvered, and racist practices of colonial expansion, especially European imperialism, White supremacy, settler colonialism, chattel slavery, and in more recent years by the legacies of these projects.

Race was, however, eerily absent in the literature on language teaching until relatively recently. Responding to a growing awareness of the topic's weighty significance, Kubota and Lin cautioned in 2006 that the field of language teaching was 'in dire need of an explicit exploration of race' (Kubota \& Lin, 2006, p. 472). Increasingly since that time, a growing understanding of the centrality of race in language teaching and of the broad range of ways race shapes learning experiences-and indeed lives-has drawn attention to race as a topic of ever-urgent concern for scholars across fields including language studies and education. Issues of race have particularly been pushed to the forefront of global consciousness over the past few years with the rise of populist and nationalist movements around the world that have centered racism and White supremacy, making this critical literature review particularly exigent. While a longer tradition of scholarship has connected race and education 
in general (Ladson-Billings \& Tate, 1995; Ross \& Pang, 2006; Leonardo, 2009; Bhopal \& Preston, 2012), it has been only over the past two decades that we have seen a significant increase in interest in an exploration of the inseparability of race from language teaching specifically.

In this review article, we outline the genesis of the research on race and language teaching, define key concepts, review relevant literature according to five themes, and offer a synthesis of the current status of scholarship on this topic and implications for future directions. Given the limited period during which a greater part of the work on race and language teaching occurred, we focus most of our literature review on the period beginning in 2006 when the seminal works on race and language teaching from Kubota and Lin (2006) and Curtis and Romney (2006) were published, although we acknowledge several important early pieces (Amin, 1997; Ibrahim, 1999; Mackie, 2003). We conducted two rounds of literature searches, utilizing the following databases: World CAT (general search), EBSCO Academic Search Complete, EBSCO Education Source, and Linguistics and Language Behavior Abstracts (ProQuest). In the first round, we searched using every possible combination of the following terms: 'race,' 'language teaching,' 'ethnicity,' 'language pedagogy,' 'Whiteness,' 'racialized,' 'antiracism,' and 'nativeness.' For the second round of our literature search, we searched using terms that we saw emerging from the literature such as 'racial identities of language learners,' 'racial identities of language teachers,' 'language varieties and language teaching,' 'race and language teacher education,' 'race and educational policy,' 'race and language programs,' and 'race and language curriculum' and also repeated our earlier searches in order to keep the literature updated. These searches failed to capture the body of work on the teaching of indigenous languages and on language revitalization, most of which did not directly name race, so we subsequently conducted searches using these two terms and examined that literature for its attentiveness to race.

As we worked, we were reviewing a body of literature that attempted to examine the workings of race somewhat apart from different intersectional axes. It might be argued that shining a light specifically on race allows us to more clearly see how race carries invisible consequences for language teaching. However, the deeper we moved into the literature, the more aware we became of the problematic nature of this limited and reductionist perspective, which is itself yet another legacy of colonial thinking (Mignolo, 2003). We recognize that race needs to be conceptualized in the context of its relationality with gender, sexuality, nationality, religion, class, language, and other layers of identity, and especially within language studies as part of an intersectional approach (Romero, 2017).We return to a discussion of the complications of doing so in Section 4.

An additional tension that we negotiated was that a significant part of the literature did not name race specifically, but we could see clearly that race was an undertone throughout the discussion or analysis. This was true, for instance, in much of the literature about teaching or revitalizing indigenous languages (e.g. Reyhner, 2015; Sherris \& Peyton, 2019). In one example, Underriner and Jansen (2018) described a partnership with tribal language programs and elders that prepared teachers to teach Chinuk Wawa and Ichishkín at the University of Oregon and Lane Community College, in Eugene, Oregon. Their commitment to teaching in a way that represented the languages' long and continuing culture, place-based ontology, and history held for us deeply racialized concerns. However, because race was not a part of the authors' discussion or analysis, and because including it would have required us to offer an extended discussion of our own interpretation of not the text but the sub-text, and furthermore because of our space limitations, we did not include pieces such as this one in our discussion. This body of literature is, however, a vibrant and important one, and we recommend that Language Teaching commission a separate article that engages with these complexities.

Similarly, we were guided by a body of literature in which 'language teaching' was often conceptualized in a narrow sense of taking place within classroom walls in a traditional language classroom. This understanding does not include the vast range of language development taking place in natural contexts outside classrooms, in instructional programs that are not language-focused, or in informal or incidental learning. While we recognize and in fact honor contexts of language teaching as expansive and unbounded, for the purposes of this article we allowed ourselves to be guided by the literature. 
Therefore, we included a piece only when its authors wrote about the content specifically in terms of language teaching.

Finally, we acknowledge the hegemony of English (Phillipson, 1992; Skutnabb-Kangas, 2000; Pennycook, 2001; Block, 2010; Kramsch, 2014) in the geopolitics of scholarly publishing (Canagarajah, 2002). We focused on literature available in English, only a small portion of which addresses teaching languages other than English. We acknowledge the importance of reviewing literature multilingually to examine how issues of race and language teaching are addressed in diverse contexts and recognize that one unintended consequence of reviewing literature published in English is that other languages become marginalized. We therefore struggle with our own participation in maintaining inequitable dynamics in a world in which an unjust degree of prestige is bestowed upon scholarly work published by English language journals and presses. We did observe that the conceptual importance of the English language studies we reviewed was frequently transferable to the teaching of other languages. For instance, unpacking Whiteness in teacher identity (Liggett, 2009) is important for English, with its long history of associations with Whiteness, but it is similarly relevant to many other languages from the Global North, such as German (Müller, 2011). In a parallel vein, the notion of inner circle and outer circle countries (Kachru, 1992) has emerged from the colonial past of English, but it is necessary that we understand the similar ways that discrimination across language varieties is intertwined with national histories of conquest, colonization, and occupation across all of the major languages (Smith, 2019). We revisit these concerns in Section 4. We also acknowledge that much of language teaching is carried out in institutional contexts that assume static boundaries around and between languages. Our discussion of pedagogical practices takes place in the context of these formulations, which do not reflect actual dynamic and translingual patterns of language use in the contemporary world (Makoni \& Pennycook, 2007).

\section{The genesis of the research on race and language teaching}

The year 2006 was an important one for race in language teaching. It was during that year the first significant volumes that focused explicitly on race and language teaching were both published: Kubota and Lin's special issue of TESOL Quarterly on Race and TESOL and Curtis and Romney's collection of narratives by English language teaching professionals of color, in which scholars theorized the intersections of race and language teaching. In the introduction to their special issue, Kubota and Lin (2006) noted the lack of serious inquiry into ideas about race and pointed out that the field 'has not sufficiently addressed the idea of race and related concepts' (p. 472). Prior to 2006, only a handful of pieces had addressed this intersection, for instance Amin's (1997) study, one of the first connecting perception of English-speaking ability and English teaching ability to Whiteness and nationhood (specifically Canadian and U.S. nationality); Ibrahim's (1999) ethnography of French-speaking African refugee youth in Canada who teach themselves Black English; and Mackie's theorization of the role played by desire - including desires for Whiteness and for racial Others within the teaching of English. Contributors to the Kubota and Lin special issue (2006) addressed a range of questions that engaged with race in language teaching, including the implications of teachers' privileged status as native speakers, a raced category, and standardization and language hierarchies (Motha, 2006a); the effectiveness of anti-racist education (Taylor, 2006); and the racialization of researcher identities (Lee \& Simon-Maeda, 2006). That same year, Curtis and Romney (2006) similarly noted an absence of attention to issues of race, commenting that work to date contained a contradiction, that is that 'color and race appeared only as asides or were in the background. However, in our experiences, race and color were usually very much in the foreground' (p. xii). Bringing together the voices of racially minoritized scholars in English language teaching, their edited volume explored themes as wide-ranging as exceptionalism (Nero, 2006a), racial frames (Fujimoto, 2006), discourses of safety (Motha, 2006b), perpetual foreignness (Wong, 2006), stereotypic views (Tinker Sachs, 2006), and legitimacy of language identity (Lin, 2006). That same year, Marx (2006) published her monograph focused on Whiteness and teaching, Revealing the invisible. While much work linking race and 
language teaching examines racially minoritized perspectives or experiences, Marx's book was part of a newly emerging scholarly focus within education and the social sciences on Whiteness. Exploring the developing racial consciousness of nine White female tutors teaching students of color, Marx considered the consequences of their practice and racism for the lives of their students, and offered recommendations for anti-racist language teacher education. In 2009, Kubota and Lin (2009) continued to push the field's thinking about race and language teaching with another seminal collection, Race, culture, and identities in second language education. These books focused on race and the teaching of English. At the same time, while some attention was being paid to the connections between race and languages other than English (Talburt \& Stewart, 1999), we did not see this attention specifically focused on teaching. Since that period, other individual studies and theoretical undertakings, in the form of books, journal articles, or book chapters, have continued to be published, and recent years have seen even greater attention to race and language teaching within the research literature.

In the next sections, we begin our review by conceptualizing two key terms, 'race' and 'language,' followed by an overview of the theories that appeared to us to be most prominent in the research literature to date. We then explore five themes that featured prominently throughout the existing literature on race and language teaching, and analyze the gaps and reframings needed in the literature. We conclude with implications and questions arising from the work.

\section{Defining terms}

\subsection{Conceptualizing 'race'}

'We do race, all of us, every day. The challenge we face now is to learn how to stop doing race' (Moya \& Markus, 2010; in Lee, 2015, p. 92). For many centuries, race was assumed to be biologically determined, but recent genetic research has helped us to understand racial difference as a social construct (see Kubota \& Lin, 2006). The material consequences of perceived phenotypical difference among groups of people are real and create racial hierarchies and inequalities. Conceptualizations and meanings of race are inconstant and dynamic, but within the literature on language teaching, five common concepts resurface consistently when definitions of race are described.First, the notion of race cannot be disentangled from the context in which it was invented, that is colonialism. Our definition of colonialism is broad and includes a range of origins-settler colonialism and land seizure, the transatlantic slave trade, forceful invasion and occupation, Christian missionary efforts, and the epistemic violence and resulting legacy that persists today. Historically, theoretical work knitting together race and language has been underpinned to some degree by postcolonial theory, from early theorists such as Frantz Fanon, Chandra Mohanty, Gayatri Spivak, Edward Said, and Albert Memmi to more recent language education scholarship, such as the work by Suresh Canagarajah, Alastair Pennycook, Robert Phillipson, Hyunjun Shin, and Angel Lin and Allan Luke. Scholars working from this tradition acknowledged that the concept of race was invented to support and justify colonialism, and recognized that 'racism is not simply a by-product of empire but an intrinsic part of it, part of the intestines of empire' (Pieterse, 1990, p. 223). Race and empire can consequently not be conceptualized apart from one another (Motha, 2014).

Second, as mentioned earlier, racial categorization is socially rather than biologically constructed (Kubota \& Lin, 2006, 2009; Luke \& Lin, 2006). Historically, scholars often made a distinction between RACE and ETHNICITY by using the former term as associated with perceived physical characteristics, while the latter term was purportedly more often used to refer to cultural, national, or social affiliations. Within this framing, race was conceptualized as a broader category than ethnicity, with fewer races existing and numerous ethnicities available, in theory, within each race (Fitzgerald, 2017). However, we have come to understand that both the phenotypical and the cultural, national, and social affiliations at the root of the distinction between race and ethnicity are themselves social constructions developed in order to categorize and classify humans, inevitably leading to systems of ranking, hierarchy, and oppression. Within this work, therefore, we use the terms with a consciousness that the two cannot be cleanly disentangled because of the subjective, problematic, and inherently reproductive nature of their construction. 
Third, the boundaries considered to exist between and around racial groups have changed over history and shift depending on nation, context and community (Ferreira, 2007). Racial categories are fluid across time and space; for instance, the categorical meaning of Whiteness in the United States has shifted over history. Roediger (2018), in fact, argued that the concept of Whiteness itself has nationalism at its roots and is a U.S. construct.

Fourth, while race is a significant social construct affecting different groups of people in their private, social, and institutional lives, race is not the single category that produces such significance. Race intersects with other attributes, such as gender, class, sexuality, ability, language, and culture, forming complex human experiences and social structures (Kubota, 2015).

Finally, racialized ideologies are embedded in the practices of language teaching, although the degree to which these ideologies are recognized as racialized varies widely according to context (Kubota \& Lin, 2009; Motha, 2014; Jenks, 2017). A significant body of work, including work from sociolinguistics, anthropology, and cultural studies, connects race and language use without a specific focus on language teaching. This work is relevant to, helps to shape, and is influenced by the work on language teaching, but because it is beyond the scope of this literature review, we mention it only briefly here in order to alert the reader to its relevance.

\subsection{Conceptualizing 'language'}

How 'language' is conceptualized shapes how and what we teach in relation to language, curriculum, and how language learning students are perceived. Who gets to define what counts as language ultimately shapes the potential of those learning it. 'Language' has historically been conceived of as bounded into discrete, clearly-defined entities such as 'Spanish' or 'Somali' with some recognition of language variation within each named language (Makoni, 2012). More recently, however, theorists have begun to question conventional understandings of language and language use, approaching languages instead as socially constituted, fluid semiotic systems. This shift in perspective challenges the notion of distinct boundaries and categories of language in what Kubota (2016) has termed 'the multi/plural turn in applied linguistics.' We see this trend marked by, for example, increased theorizing around translingualism (Canagarajah, 2013), translanguaging (García \& Wei, 2014), multilingualism (May, 2014), metrolingualism (Pennycook \& Otsuji, 2015), and superdiversity (Arnaut, Blommaert, Rampton, \& Spotti, 2016). All of these approaches argue for a definition of 'language' that is more fluid, 'denaturalised' (Blommaert \& Rampton, 2016), seen as one semiotic among many, and reflective of mobility, globalization, and the real-life language practices of bilingual and multilingual people.

The implications of the multi/plural turn of language learning, teaching, and education are not without challenge. Scholars have begun to shrink from wholeheartedly embracing the multi/plural turn and to critique the often power-evasive and ahistorical nature of its positionings. Kubota has pointed out that movements toward fluidity and hybridity of language sometimes work against efforts that draw on the collectivity and political strength of unified minority voices and can similarly obstruct indigenous language maintenance and revitalization efforts, and she notes that access to the cosmopolitanism and class privilege that often go hand in hand with translanguaging are inequitably distributed globally. We would highlight in particular that these disparities in access are intensely racialized. Flores (2013), in a similar vein, has cautioned the field against uncritically embracing plurilingualism as a goal, noting that this push at the same time exerts pressure to produce a neoliberal subject flexible enough to generate capital in a variety of manners, contexts, and jobs. He urges us to focus more closely on 'unexamined power relations in current theories of plurilingualism' (p. 501). In this article, we seek to negotiate these delicate tensions in meanings of 'language' while still staying close to the usage and conceptualization of the term throughout the literature related to race, and language teaching more specifically, through instruction, curriculum, and learning opportunities within and outside the classroom. 


\subsection{Theories used in framing literature}

A wide range of theoretical frameworks and traditions informed the work surveyed in this article. One of the most prominent is critical race theory (CRT), a set of theories that emerged from legal studies in the United States in the mid-1980s that recognizes White supremacy and institutionalized racism as an inherent and permanent part of U.S. society. A basic assertion of CRT is that equal protection for all humans under the law cannot be achieved unless White supremacy enshrined within the legal system is confronted. CRT ultimately became highly influential in educational studies (see Ladson-Billings \& Tate, 1995) and across numerous other fields with a particular focus on everyday encounters of racism, which are frequently exposed and resisted through counter-storytelling. Many studies in this literature review relied heavily on the framing from CRT to examine different areas related to language teaching such as language pedagogy, language teacher education, and language education policy. CRT has also spawned several newer, interdisciplinary offspring that extend and problematize CRT through lenses of Southern theory, most notably theories shaped by knowledge of Latinx, indigenous, Asian, and South Asian communities through LatCrit (Solorzano \& Bernal, 2001), TribalCrit (Brayboy, 2005), AsianCrit (An, 2017), and DesiCrit theories (Harpalani, 2013). Another progeny is LangCrit (Crump, 2014; Morita-Mullaney, 2018), a theoretical framing situated at the socially mediated intersection of race and language that considers how this intersection informs identities. LangCrit is beginning to inform some newer studies being published and is particularly focused on language teacher and student identities.

In recent years, critiques of settler colonialism have offered new understandings of the relationship between race and language teaching. Previously, most work in language colonization was underpinned by postcolonial theories, which for the most part considered conditions that have been termed exploitation or external colonialism (Paperson, 2017), related forms of colonialism in which a smaller number of people came to a territory seeking to steal resources and extract labor from the inhabitants, but not necessarily wanting to occupy the land (Tuck, Mackenzie, \& McCoy, 2016). The ongoing legacy of language teaching in these contexts therefore largely relies on the construct of race to create language hierarchies and establish original languages as inferior. Settler colonialism has somewhat different goals, resulting in different consequences. A goal of settler colonialism is to take and maintain possession of land, occupy it, convert it to capital, and eradicate the inhabitants, insisting that the land had been empty. Extinguishing indigenous languages and any associated capital therefore becomes an important ongoing goal of settler colonialism. Teaching languages in settler colonial contexts takes a different positioning than teaching under conditions of external or exploitation colonialism, and we see theories of settler colonialism illuminate in different ways our understandings of how language teaching interacts with race. A great deal of the work on indigenous language revitalization is embedded in settler colonial theory, which therefore informed our exploration, but much of this work did not include the concept of 'teaching' in the narrow sense of post-contact schooling in formal schools and is therefore not included here. For instance, Navarro (2016) described indigenous hip-hop artists' language resistance throughout the Americas by teaching, for instance, Ojibwe, Nahuatl, and Kichwa through their songs, revitalizing oral traditions and radical orality, and in the process of building alliances. A separate review of this literature would be a valuable contribution to Language Teaching.

As we return to later, more recent work on race and language teaching is situated within the fresh and vibrant research area of raciolinguistics (Flores \& Rosa, 2015; Alim, Rickford, \& Ball, 2016). While Alim etal., (2016) volume investigated the linguistic experiences of racialized subjects through a primarily sociolinguistic lens, Flores and Rosa (2015) critiqued the White gaze in educational contexts in which 'raciolinguistic ideologies produce racialized speaking subjects who are constructed as linguistically deviant even when engaging in linguistic practices positioned as normative or innovative when produced by privileged white subjects' (p. 150). In future work, we expect to see the influence of raciolinguistics research extending from language use more explicitly to language pedagogy.

Conceptual lenses that captured the ignoring or denial of race play a significant role across the literature. These include colorblind ideologies (Bonilla-Silva, 2014), color-evasiveness (Frankenberg, 
1993), colormute discourse (Pollock, 2004), or cultural racism or new racism-discourses that actively avoid using words referring to race. One example is a focus on culture rather than race (Marx, 2009; Lee, 2015), and another is the notion of racism without racists (Bonilla-Silva, 2014), which encompasses the repertoire of arguments, discourse, and narratives used to justify racial inequalities. These concepts and frameworks inform much of the current and existing literature on race and language teaching.

Also present in the literature were glimpses of work on racial capitalism, drawn from cultural studies (Melamed, 2011), and we anticipate this set of theories to become more influential moving forward. Racial capitalism presumes that all production of capital is dependent on deeply uneven relations between groups, which has historically been predicated on the construction of racial categories. Using this disciplinary lens allows questions about how language teaching reinscribes racial hierarchies that propagate and exploit an inequitable order.

\subsection{Current themes in race and language teaching research}

Given the overwhelming amount of attention paid within the academic literature to the role of race and racism in teaching, learning, and education in the mainstream classroom (Mitchell, 2012), we were surprised to not see more research connecting race with issues of language teaching and pedagogies, with the exception of existing research that focuses on the racial identities of language learners and teachers. Several important themes ran through the growing number of research studies that focus specifically on race and language teaching. We highlight and examine in greater detail researchers' key claims that ran through the studies providing insights into race and language teaching, identity, curriculum, and language teacher education. We saw five interconnected themes within our analysis:

1. Standard language ideology and racial hegemony

2. The idealized native speaker with racial labeling

3. Racial hierarchies of languages and language speakers

4. Racialization and teacher identity

5. Race-centered approaches to pedagogies and educational practices

\subsubsection{Theme 1: Standard language ideology and racial hegemony}

For many globally powerful languages, most notably English, the desirable language form, which becomes constructed as a 'standard,' is associated with Whiteness and colonial power (i.e. White European or White American power) and therefore plays a powerful role in maintaining White hegemony. These idealized forms of language came to be conceptualized as 'standard' and instrumental in maintaining White supremacy and White hegemony (Lippi-Green, 2012). Nero and Stevens (2018) nine-month critical ethnographic study in three Jamaican schools, for example, allowed a glimpse into the ways that Jamaican Creole came to occupy a low status while Standard Jamaican English became privileged in schools, resulting in markedly different teaching practices. Focusing their analysis at the intersection of social class and language, the authors described legacies of colonization in shaping societal attitudes toward Jamaican Creole and Standard Jamaican English, and consequently language education. While they did not say so specifically, it was clear that Standard Jamaican English was more closely associated with Whiteness than Jamaican Creole.

The language standardization ideologies in the literature most often examined the notion of a 'Standard English,' which we understand to be a 'bias toward an abstracted, idealized, non-varying spoken language that is imposed and maintained by dominant institutions' (Lippi-Green, 2006, p. 67), in schools, language policies, and education in general. In their examination of the teaching of English in South Korea and racialized language attitudes in the United States, Grant and Lee (2009) showed how language policy equated 'Standard English' with English associated with Whiteness while creating educational, social, political, and economic barriers for speakers of African-American Vernacular Englishes (AAVE), indigenous languages, and other linguistic varieties. 
In the South Korean context, this racialized Standard English was regarded as an important marker of linguistic capital, resulting in national education policy that prioritized (Standard) English language learning in its national education policy agenda and the higher demand for (White) English as a foreign language (EFL) teachers and education (Grant \& Lee, 2009).

At the school and classroom levels in California, Malsbary (2014) showed how Standard English ideology associated with White supremacy created hostile conditions for immigrant and bilingual students of color through 'teachers' substantiation of English-only policies, students' arguments for English-only use in classrooms, and students' policing of each other's language practices' (p. 382). Through practices that affirm standard English ideology, educators positioned 'students who are Standard English speakers as the idealized norm and children who are speakers of other languages and dialects as racialized Others' (Fránquiz \& Ortiz, 2017, p. 335). This positioning 'makes the acquisition of standardized language codes equivalent to the acquisition of whiteness' (Fránquiz \& Ortiz, 2017, p. 335). In her ethnographic studies of four South African schools, McKinney (2017) showed how Standard English ideology, English-only policies, and White supremacy operate together through what she coins, 'anglonormativity.' Similar to Fránquiz and Ortiz, McKinney showed how anglonormativity positioned students from nondominant backgrounds as deficient through mechanisms such as teacher and student discourse regarding what was considered to be proper pronunciation and appropriate use of English words, and stigma associated with Black varieties of English.

Anglonormative contexts have also been shown to be powerful in shaping racist ideologies about language and the race of language teachers, even when teachers actively work to challenge racial and linguistic hegemony. For example, while not specifically focused on language teaching, Orzulak (2015) used discourse analytic and qualitative methods to examine the tensions preservice teachers experienced between adopting raciolinguistically responsive stances that valued student language variation-particularly AAVE-and enacting these stances through their pedagogy when their broader contexts privileged (White) 'standard' English(es). Orzulak called these tensions, 'linguistic ideological dilemmas' that often resulted in quelling the teachers' focus on equitable teaching. She argued for preparing preservice teachers for conversations about language variation and a greater understanding of 'language-related ideological triggers' (p. 176). These studies, along with others, called out the need for language teacher education curricula that explicitly focus on White privilege (Faust, 2016) and antiracism to counter White normativity and the teaching of the English language through American or British culture (Jenks, 2017). Anti-racist pedagogy addresses the intertwined nature of race and language teaching, and supports students in recognizing and making visible the racialized nature of language and critically analyzing 'the English language, its promises, and the practices involved in the teaching industry' (Motha, 2016, p. 114).

Resisting racial hegemony. In the face of these overwhelming forces of White supremacy, a few studies have also begun to identify different ways that students in particular have resisted the hegemony of English and Whiteness they experience in their schools and classrooms. The two female Taiwanese second language (L2) writers in Liu and Tannacito's (2013) study of a U.S. English as a second language (ESL) writing class, for example, chose different ways to disrupt their experiences with English writing within the context of the class construction of 'Americanness' and 'Whiteness.' One student resisted peer editing in the writing process as she saw this as a 'White American way of writing' and not a Chinese way of writing. The second student disengaged from the class as she did not think the ESL writing class was helping her to learn how to write 'good' essays that were 'beautiful' and 'longer' as she understood American writing to be.

Other studies showed students' active resistance through translanguaging practices (McKinney, 2017) and dynamic student-created multilingual policies to support their own and their classmates' academic learning (Malsbary, 2014). An ethnographic study by Endo (2016) described 1.5-generation Japanese-American adolescent students' resistance to a school culture that devalued their Japanese identifications and created racially offensive stereotypes about their perceived foreignness despite publicly promoting a focus on inclusivity. The Japanese youth in the study 'challenged English-only ideologies and racialized expectations at their school through alternative literacies and other diverse 
enactments of their identities, such as by speaking Japanese or Japanglish (a mix of Japanese and English) and expressing their 'Made in Japan' pride through the public display of nationalistic symbols and various bilingual or Japanese-language textual representations' (p. 201). In a similar manner, the Black South African students in McKinney's (2017) study challenged the restrictive White monolingual norm of their school and classrooms through their use of hybrid discursive (and literacy) practices or translanguaging, and using a wide variety of semiotic resources for learning and making meaning. Both naming and investigating race and institutionalized racism surfaced as key aspects of the schooling of multilingual learners. However, these need to be more consistently addressed in the research on language policy and programs in an effort to transform oppressive structures and practices' (Mitchell, 2012, p. 348) and educational inequities.

AAVE. One area of the research that has effectively highlighted the salience of race in language teaching, particularly in recent years, is the teaching of Englishes associated with African-American identity, variously termed Black English, African-American Vernacular English (AAVE), and in the literature from the 90s, the term now largely considered derogatory and inaccurate among many applied linguists, Ebonics (Lin, 1965; Fasold \& Shuy, 1970; Ferguson, 1982; Ramirez, 2005; Baugh, 2006).

Several pieces offered a comprehensive review of the historical literature on the formation of Black English as a construct in the context of slavery and Jim Crow, ${ }^{1}$ and the historical teaching of Black English within the U.S. context, including Wheeler (2016) and Alim and Baugh (2007). Wheeler (2016) equated Standard English with 'White' English and challenged its hegemony in dialectically diverse classrooms. She named the 'racism inherent in [fostering] bidialectalism [through teaching]' (p. 380), arguing that we are acknowledging that the only way for African-Americans to be upwardly mobile was to learn how to speak 'White' English. Alim (2010), explained, 'By uncritically presenting language varieties as "equal" but differing in levels of "appropriateness," language and Dialect Awareness programs run the risk of silently legitimizing "Standard English"' (p. 215). The result, Wheeler argued, has been that classrooms and teaching have focused on correcting or eliminating AAVE features from students' oral and written language. Wheeler, however, concluded that improving teachers' attitudes towards vernacular speech and vernacular speakers was not enough. Rather, what was needed were standards, tests, and materials that 'require teachers to distinguish patterns in vernacular dialect from error in Standard English' (p. 384). Current work addressing AAVE studies has been shifting focus to translingualism and to promoting such pedagogies as code-meshing (Young, Barrett, Young Rivera, \& Lovejoy, 2014) and translanguaging (García \& Wei, 2014), embedded in a critical analysis of the racial logics underpinning the denigration of some languages. This work, combined with extensive examinations of the connections between race, language, teaching, and identity (e.g. Flores \& Rosa, 2015; Alim et al., 2016), has laid a foundation for a raciolinguistics approach to teaching, which we return to later in this article.

Certainly, much more explicit attention needs to be paid to the connections between the history of anti-Black violence in which Englishes associated with Black identity were formed and the ubiquitous presence of racism and anti-Blackness being increasingly acknowledged in the contemporary moment. We recommend a state-of-the-art article critically reviewing the historical literature on the teaching of Black Englishes or AAVE in the contemporary context of intensified anti-Black racism and \#BlackLivesMatter.

\subsubsection{Theme 2: The idealized native speaker and White supremacy}

Standard language ideology is intertwined with White supremacy and another often examined phenomenon in the growing race and language teaching literature-the idealized 'native speaker'-

\footnotetext{
${ }^{1}$ The term 'Jim Crow' refers to the practice of racial segregation, discrimination, and oppression based in White supremacy and leading to a legally mandated system of apartheid across the South in the United States during the late nineteenth century and through to 1965 .
} 
particularly with regard to the teaching of English and other European languages (Nero, 2006b; Saraceni, 2015). The idealized English speaker is often imagined as White (e.g. Nero, 2006b; Grant \& Lee, 2009; Saraceni, 2015; Yamada, 2015). This idealized ideology of White English speaker promotes inequality and oppression among language teachers and language teaching in multiple ways. For example, the association of 'native speaker' of English as 'White' often results in racism in recruitment and hiring. This was observed in a higher demand for White EFL teachers (Grant \& Lee, 2009) and discrimination against teachers of color (Golombek \& Jordan, 2005; Nero, 2006b; Grant \& Lee, 2009; Park, 2013; Saraceni, 2015). Austin (2009a) used CRT to examine the relationship between linguicism and race in the U.S. and its impact on teacher education in her short and selective historical review. Austin showed how educational policies from Reconstruction and post-Civil War reforms to Brown v. Board to English-only Massachusetts Question 2 legislation privileged White language teachers who spoke the more accepted 'Standard English' and regarded teachers from nondominant communities as poorly qualified. This in turn, led to recruitment of 'better' teachers who came from more privileged backgrounds. Austin argued that the historical legacy of 'excluding language-minority teachers and the current opposition to bilingual education also contributed to the lack of teachers from nondominant groups' (p. 265). Austin (2009b) advocated for improved recruitment and professional development for language teachers from underrepresented groups and curriculum that prepares teachers to recognize and address issues related to institutional racism and other forms of oppression.

Despite the vast majority of ESL or EFL teachers globally being non-native speakers (Sung, 2011), the research shows clear preferences for White and native-speaking language teachers by students, such as Japanese students in Rivers and Ross $(2013 \mathrm{a}, \mathrm{b})$ experimental study, and Ruecker and Ives (2014) analysis of 59 websites recruiting for language schools in China, Japan, Korea, Taiwan, and Thailand. Ruecker and Ives showed entrenched patterns of representations of English teachers as young, White, native speakers from a limited list of countries that all have majority White populations. Similarly, Jenks (2017) analysis of discourses surrounding the English language teaching profession in Korea highlighted the complicated ways that all participants in the language teaching industry help to construct a condition of 'White normativity,' particularly in teacher identity, which sustained racial discriminatory practices at all levels of the industry, from national-level hiring practices to media advertising to local-level classroom pedagogies.

Takahashi (2012) explored more deeply the idealization of Whiteness in relation to English speakers in her qualitative study of young female Japanese sojourners in Australia. Takahashi argued that for her participants and many like them, English language acquisition was intertwined with romantic desire [agokare] for a White, Western male partner; proximity to Whiteness and Western identity; mobility; and identity transformation. While her study did not provide in-depth analysis of language teaching, it illuminates for educators the interrelatedness of learner (racial) identities and language desires, investments or purposes for learning English (Motha \& Lin, 2014; Lin \& Motha, 2019) and raises questions about how better developed understandings of the interrelatedness of learner identities, gender, and language desires might better support language teaching. Similarly, Stanley (2013) drew on her ethnographic study in China, arguing that the symbolic role of White native speakers of English was more aptly described with foreignness and Westernness, which contrasted with nationalistic identity of Chineseness of the learners. As such, White native English-speaking teachers are expected to perform Whiteness.

White supremacy, however, also affects who is considered for teaching positions of languages other than English. In Kubota's (2009) study, the idealized speaker of Japanese is not-White, yet the researcher saw White supremacy at play in relation to Japanese teacher identity in a high school in the U.S. south. A Japanese teacher with strong pedagogical skills was passed over for a Japanese-as-a-foreign-language teaching position at a U.S. high school, while a more racially desirable White American nonnative speaker of Japanese with poor pedagogical skills was hired instead.

The recurring themes of White, native English-speaker hegemony (Yamada, 2015), White English as the desired 'standard,' and the inferiority of the languages of students of color were also predominant in studies of language curriculum (Taylor-Mendes, 2009; Mitchell, 2012; McKinney, 2017). 
Sarah Michael-Luna's detailed (2008) analysis of moment-to-moment interactions in a first-grade dual-language classroom in the United States revealed how the practices, texts, curricula, and ideologies of schooling create contexts in which children made complicated decisions about racial identification. The Spanish-speaking students in Michael-Luna's study found themselves negotiating limited identity options (i.e. Black identity or White identity) and limited social power and experienced representations of themselves as absent in school metanarratives.

The idealized White English speaker in language curriculum was particularly emphasized in EFL educational research. These studies critically examined visuals and EFL textbook images that reinforce stereotypes and construct problematic monolithic racial and cultural identities, such as White as wealthy, powerful, American, and economic and socially successful, and minorities as poor and powerless (Taylor-Mendes, 2009; Yamada, 2015). This often resulted in EFL students developing limited understandings of English-speaking nations through their EFL textbooks. These studies called for EFL teaching and curriculum that challenged monocultural and monolinguistic attitudes and that were based in diversity and multicultural perspectives, such as the use of images or textbooks with images that illustrated complexity of speakers, situations, and locations as well as including critical examination of EFL textbooks and discussing what the image implies (Taylor-Mendes, 2009; Mitchell, 2012; Yamada, 2015; McKinney, 2017). In general, however, the literature on race and language teaching curriculum is sparse. More work is needed on the analysis of imagery appearing in curriculum and materials as well as representations being offered of speakers of languages other than English.

\subsubsection{Theme 3: Racial hierarchies of languages and language speakers}

Schooling practices reflect racialized hierarchies of languages and language speakers, positioning languages and speakers associated with Whiteness as more valued and racially minoritized languages and speakers as less valued or even erased. A growing tradition of research problematizes the historical mapping of race onto language in a linear, one-to-one manner. This research draws attention to the inextricability of race from the broader sociopolitical contexts, such as assumptions about who speaks a given language, rights to language, appropriation, heritage language promotion, and belonging, often resulting in racialized hierarchies and variation in raciolinguistic value of languages and language speakers. Nero's (2006b) work took a global perspective, drawing on theories of linguistic imperialism, macroacquisition and creolization to show the ethnocentrism of applied linguistics and English language teaching (ELT) professions that privileged linguistic competence in what she termed 'Anglo dialects' of English such as General American English or British English, even if none of the interlocutors were 'Anglo.' She argued that ELT needed to challenge Anglo-American ethnocentrism through curriculum and pedagogy that encouraged respect for all varieties of English (e.g. AAVE; Hawai'i Creole English; Hispanized English) and utilized a bidialectal/bilingual approach to language instruction; validating the ties between language, ethnicity, and student identities.

Some studies make visible this close connection between linguicism and racism where language is often used as a proxy for race in creating and implementing school policies and programs (Pimentel, 2011; Mitchell, 2012; Malsbary, 2014; Marx \& Saavedra, 2014; McKinney, 2017). In general, this literature is not focused so much on language teaching explicitly as the conditions within which language teaching occurs. Rather, it highlights the 'racialization of language' (Pimentel, 2011), or raciolinguicism, where higher status is given to English or European languages associated with Whiteness and lower status is assigned to languages spoken by students of color. Even the notion of 'language varieties' plays a powerful role in maintaining White supremacy by creating the conditions in which hierarchies became naturalized. For example, in their critical reflection on a failed university-school district partnership, Marx and Saavedra (2014) examined how efforts to redesign an ESL program were undermined by 'linguistic racism.' These scholars highlighted how district officials 'demonized' Spanish as a native language in schools and held clearly deficit perspectives of their Latinx students, rejecting bilingual education recommendations. The resultant ESL 'redesign' focused on language 
teaching based in repeating words when prompted and an emphasis on passive student behavior. In contrast, the same school district offered more highly valued Chinese classes to primarily White, native English-speaking students where language teaching focused on providing rich language and cultural learning experiences.

Such raciolinguistic hierarchies in language teaching contexts result in inequitable educational opportunities for language learners. In his ethnographic study of language diversity in a Cape Town public school, Collins (2017) showed how schools assigned English and Afrikaans as 'standard' languages associated with higher status White South Africans, and African languages as 'nonstandard' languages of lower status Black South Africans. The result was the development of 'systems of education that offered stratified linguistic choices' (p. 51). Similarly, Kubota and Catlett (2008) identified racial implications for WHAT languages may be taught, normed, or emphasized in language teaching contexts through their study of a school initiative that shifted the focal language of an existing U.S. Foreign Language in the Elementary School (FLES) program from French to Spanish. Pushback from resistant teachers, students, and community members was not based on an understanding of best educational practices, program goals, or bilingual theories, but rather 'commonplace assumptions and speculations, reflecting larger discourses of talk about language, language learning, race and ethnicity' (p. 110) where Spanish language instruction was associated with Latino and African-American students and 'providing skills for blue-collar and service jobs' while French was associated with White Europeans and preparing students for more 'white-collar and sophisticated jobs' (p. 112).

In a similar manner, racial prejudice and specifically anti-Blackness have also been shown to exclude Black students 'from meaningful participation in foreign language education and equitable access to resources that reduce their isolation in our globalizing world,' (Anya, 2017, p. 5). While not a pedagogical effort in the traditional sense, Anya's (2017) recent study shone a light on the low participation rates of African-Americans in study abroad and foreign language programs and offered detailed ethnographic descriptions of the pedagogical experiences of four AfricanAmericans studying Portuguese as part of a study abroad experience in Brazil. Anya noted that the individuality of black experience means that 'African-American lives are powerfully mediated by race and fundamentally shaped by racialized consciousness and identities' (p. 5). Using an ethnographic lens to study four students, Anya found race to be deeply significant in the language learning experiences of her black participants and concluded that explicit links must be made between the lives of black students and the curriculum and content of all foreign language learning experiences, including study abroad.

The influence of hierarchical raciolinguistic ideologies on school and classroom policies has farreaching effects on the educational opportunities and identities of students of color in various language learning settings. Kleyn's (2010) case study of two Afro-Latino Garífuna communities in Honduras showed how racially unjust contexts and ideologies negatively influenced teacher pedagogy, resulting in negative treatment of language-minority and nondominant Garífuna students in heterogeneous contexts with dominant Ladino students, such as student-teacher relationships and educational requirements and seeing Garífuna as a barrier to learning. In her three-year qualitative study of the positioning of university-level Korean learners of English in the United States, Jeon (2010) similarly critiqued how instrumental views of language learning reinforced students' desires to shift from language-minority Korean to language majority English because of the prominent role of English in the global marketplace, thereby predisposing the students against Korean language maintenance. Both Kleyn and Jeon emphasized the role of ethnolinguistic hierarchies in determining the opportunities for language learning and called for the need to explicitly address the role of ethnicity in language education and language teacher education.

Racialized hierarchy through racialized language pedagogy. A good portion of the studies specifically emphasize the privileged role of Whiteness and English language learning in language pedagogy and educational opportunities for language learners of color. In her study of White teacher identity and ideology on instructional practices, discourse, and interactions with language learner students, Liggett (2008) found that White teachers tended to minimize, downplay, or ignore racial 
comments made by their language learner students during class discussions, resulting in students carrying negative stereotypes or connotations based on skin color. Even in contexts where a minoritized language was the focus of learning, speakers of that language were marginalized. In Harklau's (2009) study of the experiences of two Latino students, both heritage Spanish language speakers, in U.S. high school Spanish classrooms, the students described their experiences (and those of other Latino students) of being marginalized by their teacher's preferential treatment of White English monolingual students. As a result, Spanish language instruction 'distanced students from their own linguistic and cultural heritage' (p. 233) and both students became increasingly alienated from their schooling.

Dual immersion programs in the United States, which were initially conceived as a vehicle for antiracism and language rights, can sometimes work to reproduce structural racism. In a 2017 Review of Research in Education, Cervantes-Soon et al. (2017), focusing on two-way immersion programs, found that transnational emergent bilinguals' academic journeys may not be supported to the same degree as their White, English-speaking peers. Similarly, Juárez (2008) showed in a Spanish-English dual immersion program context how, within a mixed class of 'Latino' native Spanish speakers and White monolingual English speakers, the 'Latino' students were positioned as English learners and 'less qualified participants in the schooling process' (p. 245) by their teachers. In this study, teachers' colorblind and universalist orientations towards social difference among students, classrooms, and teaching practices had the effect of obscuring the salience of race and primary language in the experiences of the students in the dual immersion program. In addressing inequality through their instructional practice, the teachers focused on individual and interpersonal communication rather than systemic and institutional inequality. Juárez called for a revision of the White-centric instructional and dual immersion programmatic standards being used. Since dual-language programs were first established as a rights-based impetus for empowering Latinx English language learners, we have seen a neoliberal cooptation by White parents of bilingualism as human capital. Bilingual programs themselves have consequently undergone gentrification, with bilingualism being commodified and working to benefit mainstream English-dominant children rather than minoritized students (Valdez, Freire, \& Delavan, 2016).

Maintaining racialized hierarchies through raciolinguistic ideologies. The studies that focus on teachers' efforts to enact what they perceive as anti-racist or 'multicultural' pedagogy emphasize the strength and persistence of negative raciolinguistic ideologies in language teaching. Silences around racial identity surfaced repeatedly in the literature on language teaching. In his critical ethnography in an ESL program in a Hawai'ian high school, Talmy (2010) showed how while the students negotiate and establish racial hierarchies in the school, the pedagogical position chosen most frequently by teachers is COLORMUTE, or the anxious suppression of words relating to race (Pollock, 2004). Talmy described numerous instances of language teaching in which teachers missed opportunities to address and halt racism, and he raised questions about what instructional activities might have instead been offered in order to produce different outcomes for the racially diverse students in the study. Other teachers, while attempting to address cultural plurality and issues of race and ethnicity, were shown to have an inadequate understanding of issues of race and ethnicity and cultural plurality, such as the Brazilian EFL teachers in Ferreira's (2007) study. Instructionally, teachers' orientations to race and ethnicity in their lessons varied with some teachers being worried about addressing race and ethnicity in EFL content and some perceiving issues of race and ethnicity as a 'taboo' or 'controversial' issue.

Moreover, when present, practices that were intended to support multiculturalism or racial inclusion frequently ended up inadvertently reinforcing difference. In one example, literacy events and practices in García-Sanchez (2016) study in a classroom in Spain had the effect of reinforcing students' group membership in one of the three main racial population groups in the school: Moroccan immigrant, Spanish ethnic majority, and Spanish Roma. Teachers' patterns of student selection for in-class participation and elicitation techniques reinscribed difference, and some responses produced exoticized and essentialist notions of identity. 
Similarly, Lee (2015) detailed classroom practices in which teachers sought to create a space for discussions of cultural experience in a post-secondary ESL program. She found, though, that the pedagogical approach of cross/intercultural comparisons of cultural difference ultimately fostered the construction of otherness, and specifically racialized otherness, through discussions of national identity which became racialized, essentialist, cross-cultural comparisons in university ESL classrooms. Lee noted specifically that: 'The implicit intersection of the English language with Whiteness served to conceal the discourses of race and racialisation that populate discourses of language and culture.' More specifically, talk about 'culture' became a euphemism for 'race.' The students in Lee's study were found to internalize unexamined raciolinguistic ideologies that positioned their cultures-and therefore races-as inferior. Lee concluded, 'Doing culture in teaching ESL is often doing race in a colorblind manner, perpetuating cultural and racial essentialism, incompatibility, and inequalities' (p. 90).

\subsubsection{Theme 4: Racialization and teacher identity}

Teacher identity is a racialized ideological construct. The racial identities of language teachers figure into the profession in multiple significant ways. On a practical level, teachers' identity constructions and performances in classrooms, particularly as these relate to race, shape pedagogical practice and student learning (Varghese, Motha, Trent, Park, \& Reeves, 2016; Vitanova, 2016). At a far deeper and not easily visible level, the actual construct of teacher identity wields tremendous conceptual power in shaping the disciplinary base of the teaching profession. In her article in the TESOL Quarterly special issue on race, Motha (2006a) drew on a year-long study with four first-year teachers that explored the interconnectedness of race and language to examine how her participants' actions, words, and decisions took on particular meanings in the context of their racial identities. Motha asked how, on a deeper level, these shaped the construction of invisibly racialized meanings of the English teaching profession and in particular of institutional categories that are dependent on language identities, such as 'English to Speakers of Other Languages (ESOL).'

This is truer when teacher identity is positioned in relation to language identity, which is inevitably racialized because of, inter alia, the racialized nature of historical patterns of language contact, transmission, shift, and spread. Writing specifically about the English language, Motha (2016) noted '...the power of teacher identity ... as a construct that underpins the profession, that actually creates the logic for the profession. The construction of the language "English," and the constructions of English "learners" and English "speakers" are dependent on racial, national, and colonial formations. It therefore becomes impossible to construct English or English learners without simultaneously constructing English TEACHERs in ways that serve as a juxtaposition, as a crucial foil, as a goal, as an imagined endpoint... The ELT profession with all of its racialized and colonized ideologies becomes embodied in its teachers,' (Motha, 2016, p. 219) shaping related language ideologies and language hierarchies, such as White and not-White, settler and colonized. The racialized nature of teacher identities is particularly noticeable in the teaching of languages whose history of transmission has followed clear racial patterns, such as under conditions of colonialism. However, the mere act of teaching any language carries within it racial ideologies, such as ideologies shaping meanings of teacher/learner and native speaker/non-native speaker. An important part of understanding how race interacts with teacher identity, then, is to understand the ways in which teachers' racial, colonial, and linguistic identities underpin how the rationale for the profession is shaped (Canessa, 2007; Kubota \& Lin, 2009; Motha, 2014, 2016; Varghese et al., 2016; Jenks, 2017).

(De)legitimizing teachers of color and their pedagogy. Themes of racial hierarchy of languages and speakers, as well as the persistence of idealized native speaker ideology were also highlighted throughout a majority of the literature on language teacher identity, particularly with respect to how language teachers of color were positioned (e.g. Canessa, 2007). Most of these studies showed the hegemony of English and Whiteness in how English language teachers from nondominant and racially diverse backgrounds are marginalized and how these teachers struggled for, and (re) 
constructed their identities in relation to specific discourses of gender and racial marginalization through digital narratives in order to assert legitimacy and authority in language teaching (Golombek \& Jordan, 2005; Thomson \& Stakhnevich, 2010; López-Gopar, Clemente, \& Sughrua, 2011; Park, 2013). For instance, the three female racially minoritized language teachers in the southern part of the United States in Vitanova's (2016) study experienced challenges to their professional credibility. Often, the root of the struggle is the absence of pedagogical options that make sense for the teachers. Canessa (2007), for example, carried out a qualitative case study of Bolivian Aymara-speaking indigenous students in a highland village school, and found that teachers, who shared the indigenous backgrounds of their students, inevitably enacted practices that reproduced hegemonic racism in indigenous communities as they attempted to escape discrimination. The teachers sought to reject 'traditional' (or indigenous) life and adopting the language and manners of more socially accepted 'urban mestizos,' associated with racialized concepts of 'progress' and 'civilization,' in order to distinguish themselves from their indigenous peers. Similarly, in Thomson and Stakhnevich's (2010) case study of six South African teachers, indigenous language identities were subordinated to English identities, resulting in a parallel downward status shift in the pedagogical positioning of the teachers who identify with those language identities, often described as 'assistants' or 'translators.' The isiZulu-speaking teachers in their study initially resisted the use of isiZulu in their English classes, citing fears that allowing home languages would interfere with their young students' English acquisition.

This delegitimization of teachers of color has recently been extended to instructional leaders of color and their leadership decision-making regarding language programs. In her narrative inquiry study of three English learner (EL) leaders in a racially desegregated urban school district in the Midwest United States, including herself, Morita-Mullaney (2018) drew on a LangCrit framework (Crump, 2014) to show how districts perpetuated raciolinguicism by essentializing the leaders' racial identities. This essentialization led to the leaders' prioritization of language over race through colorblind, colormute, and nativist perspectives to achieve the goals of an EL program. Morita-Mullaney pointed to the need for researchers and practitioners to examine how language is racialized within the EL field with diverse leaders of color, which could impede or promote equitable educational access for EL students. Without this explicit focus on race, the author warned that we risk 'reproducing racism and linguicism and using language or English as our shielding proxy' (p. 15).

A body of literature describes the experiences of female racially minoritized language education teachers in the global academy as they negotiated racial and sexual violence, invisibility, and stereotyping (Li \& Beckett, 2011; Castillo-Carsow, 2012; Valverde \& Dariotis, 2020). The authors in Li and Beckett's (2011) volume describe the positioning of Asian women in higher education as 'strangers in the academy.' Other female authors of color describe disrespect and challenges to their linguistic, pedagogical, and scholarly legitimacy (Lin et al., 2004; Samimy, 2011); the tension between their privilege and their marginality (Park, 2013); and their attempts to resist being socialized into the dominant practices and ideologies of the academy (Sister Scholars, forthcoming).

Language teacher identity and pedagogy. While still relatively few in number, a small number of studies have begun to establish how teachers' (racial) identities explicitly shape their pedagogical practice (Morgan, 2004; Haque \& Morgan, 2009; Liggett, 2009; Ajayi, 2011; Motha, Jain, \& Tecle, 2012; Motha, 2014; Vitanova, 2016; Taylor, 2017). In his study of ESL teachers in the Los Angeles Unified School District, Ajayi (2011) connected the ethnic and social backgrounds of 57 teachers to their instruction. He found that in different ways, the teachers drew upon their personal histories and backgrounds-multiple variables that included the teachers' ethnicity, gender, culture, and language-to interpret and understand their role as language teachers and their students' needs, interests, and concerns. In her ethnographic study of a White ESL teacher, Taylor (2017) specifically focused on the role of 'racial touchstones,' or 'aspects of the teachers' own lives that they understand to be related to the nature of race and the experience of racism' (p. 68), in guiding the teacher's pedagogical decisions and perceptions of ESL students. Taylor found that the teacher's touchstone of being an international traveler allowed her to develop a focus on culture and avoid racial analyses, which translated 
into surface-level approaches to engaging difference in her pedagogy. She concluded that the nature of teachers' racial touchstones can shape whether and how they respond to race in their pedagogy and practice. In a similar manner, Liggett's (2009) classroom- and interview-based study of six White English teachers made connections between her participants' Whiteness and the ways in which they unknowingly read different meanings into classroom moments than did their students of color, offered different possibilities for the expression of racialized discourse, minimized or explained the significance of students' comments about race, and reinforced notions of Whiteness as normative. Liggett argued that within language education, Whiteness needs to be further unpacked because teacher identities are never neutral.

Drawing on teacher identities in pedagogy, however, can also result in positive instructional approaches. A few studies identified ways in which marginalized language teachers drew on their translinguistic and racial identities in their classroom practice to challenge racialized assumptions about their linguistic identities and legitimacy (Morgan, 2004; Haque \& Morgan, 2009; Motha et al., 2012). For example, Canagarajah (2016) applied the notion of identity-as-pedagogy in his own practice, engaging with multilingualism, interdisciplinarity, and translanguaging, reconfiguring himself and allowing his students to observe him practicing translingual forms of being, embracing the notion of 'teacher identity as a nexus of multimembership' (p. 68) in order to challenge limited notions of racial and linguistic membership. Despite these positive directions in the language teacher identity research, however, much more work needs to be done. As Motha (2016) writes, 'current conceptions of English teaching have thus far underestimated the centrality of the construct of language teacher identity within the larger project of language teaching. In particular, the embeddedness of the teaching of English within formations of race and empire is sustained in often-invisible ways by constructions of language teacher identity' (p. 217).

Language teacher education and language teacher education pedagogy. While the research continues to grow in establishing strong and complex connections between language teacher identity and pedagogy, the existing literature emphasizes the importance of teacher identity work in language teacher education and curricula that 'provide all teacher candidates a space to examine their own personal histories and the ways their biographies and attitudes may inform their future pedagogical practices' (Ajayi, 2011, p. 271). One strand of this work centers on White teachers and the need for professional development to explore their Whiteness and how it influences the teachers' perception of language learners and pedagogy (Liggett, 2008; Marx \& Pray, 2011), develop a deeper understanding of how to address race and deconstruct racism in language classrooms (Ferreira, 2007), and the need to de-center Whiteness in language pedagogy and programming (Juárez, 2008; Harklau, 2009). A much smaller strand of this work focuses on the experiences and racial identities of teachers from nondominant backgrounds, their marginalization in ELT, and implications for teacher education, such as critical self-reflection, in helping teachers to develop their identities as empowered and legitimate language professionals (Chacón, 2009), and how to assert this legitimacy and agency in ways other than changing their racial and linguistic identities (Golombek \& Jordan, 2005).

Developing critical self-awareness in language teachers in order to challenge dominant raciolinguistic hegemony is a strong theme throughout a significant portion of the literature in language teaching and language teacher education. Tools such as identity texts, dialogic ethnography-related autobiographies, and collages can support the co-creation of self-affirming identities. Additionally, they can foster teachers' ability to reflect and strategize about how to challenge, for instance, the hegemonic power of English in relation to indigenous identities, deficit views of identities associated with 'nonnative English speakers,', and the expectation to perform 'Western' English teacher identity (López-Gopar et al., 2011). Chacón (2009), for example, examined how her EFL teacher candidates and teacher educators understood and issues of race and racism in a psycholinguistics course she taught in Venezuela. Chacón's curriculum focused on having students develop critical language awareness of issues that intersect with race, language, and power through dialogical conversation on race and student journaling. She found that her students built their critical awareness of the problematic nature 
of colorblindness, recognition of their own and other students' racist attitudes, and media influence on biases, racial prejudice, and stereotypes.

A few studies more specifically advocated for drawing on critical pedagogy and pedagogies based on CRT in language teacher education to build teachers' awareness, support language teacher identities, and situate these within larger political, economic, and social issues that underlie language teaching (Álvarez, Calvete, \& Sarasa, 2012; Liggett, 2014). Cho (2017) suggested that 'the teaching of race and language be not only about racialized and linguistic identity of instructors, but pedagogical approaches and strategies through counterstories that actively foster critical reflection on power imbalance inherent in schools' (p. 666). Critical language teacher education pedagogies such as (counter) storytelling and narrative (Liggett, 2014; Cho, 2017) have shown to be powerful in allowing racially minoritized preservice teachers to critically reflect on and draw on their experiences with racism and linguicism to develop culturally relevant and racially conscious teaching strategies, such as legitimizing first language narratives (Cho, 2017).

The Canadian ESL/EFL teacher candidates in Kubota (2013) examined two important topics in local Vancouver news-Mandarin immersion education and the Winter Olympic Games-to 'notice, analyze, and problematize taken-for-granted ideas in familiar events in their community' (p. 145). They identified, for example, how issues of language acquisition in Mandarin immersion education was intertwined with assimilation and the supremacy of English and White culture. After critically analyzing these two topics, the teacher candidates were asked to develop instructional activities with learning objectives for future language learners that addressed race and racism, such as the Winter Olympic Games. Wooten and Cahnmann-Taylor's (2014) study of 15 United States world language preservice teachers during their student teaching and capstone (final undergraduate project) seminar also found that rehearsing racialized classroom challenges and interactions with students, parents, colleagues, and superiors, helped the preservice teachers to begin to develop a more complex and 'polychromatic view of interlocutors' multiple histories and investments' (p. 192). They drew on the dramatic technique of Boalian Theatre developed by Augusto Boal, a Brazilian playwright and activist, who used theater to invite both actors and audience to collaboratively explore alternative actions for social justice (Boal, 1995, 2002). Wooten and Cahnmann-Taylor argued that this theatrical approach to world language teacher preparation could help deepen the preservice teachers' critical language awareness in their first language (L1) and a more critical and connected approach to L2 instruction.

Language teacher learning and development of anti-racist pedagogies or pedagogies that specifically address race and racism, however, are currently underdeveloped areas of research. What is needed is more research on how anti-racist pedagogies are being learned and utilized by preservice language teachers to the benefit of their students and how they are synthesizing the strategies and pedagogies into a coherent and comprehensive framework for language teaching that guides preservice teachers' decision-making, interactions with students, and instructional actions. Moreover, a large portion of the studies on race and language teacher education focuses on the learning and development of White teachers. Important questions arise regarding how racially and linguistically diverse teachers experience and reify what they learn in their language teaching pedagogy and the role race plays in this process. Much work has already been done on race and teacher education more generally and holds many promising directions for language teacher education more specifically such as cultural self-study in teacher education programs, culturally responsive relationships-focused pedagogies, and developing critical pedagogy skills (Keengwe, 2017).

\subsubsection{Theme 5: Race-centered approaches to pedagogies and educational practices}

Scholars have developed some promising approaches toward language pedagogies, instructional approaches, and practices that center race. These pedagogies mainly focus on addressing and creating space for students to grapple with their racial and linguistic identities and experiences, and build students' understanding of racism, racialized power dynamics, and discrimination (Michael-Luna, 2009; Roy, 2016) through, for example, dialect awareness; critical hip-hop language pedagogies; Latinx 
language practices and literacy education; language, literacy, and pedagogy of Caribbean Creole English speakers; and literacy instruction of vernacular and Creole speakers (Farr, Seloni, \& Song, 2010). Wong and Grant (2016) argued for using the concept of 'double consciousness' (Du Bois, 1903/1961). The concept of 'double consciousness' named the challenges that students learning English as an additional language face knowing that they are being judged and evaluated by unmarked (racial) dominant standards (i.e. White European Americans or Anglo Americans). 'Double consciousness' served as a tool to help language learners understand and affirm their identities and histories, and to criticize normalized and dominant discourses that lead to shame about language use or accent, or that established a conflict between English learning and promotion of home language, culture, or community.

In Michael-Luna's (2009) two-year ethnographic study of students in a first-grade Spanish-English bilingual classroom, counter-storytelling and narratives from CRT were guiding aspects of the teacher's pedagogy. The teacher used cultural-historical figures, including Cesar Chavez, Diego Rivera, and Frida Kahlo, to create counternarrative texts in his literacy instruction, challenge dominant representations of Latinx identity, and 'make being Latino a valuable property' (p. 246). He also included Mexican and South American-origin leaders in curriculum and showed them as agents of change. In addition, during common classroom instructional routines, such as calendar time and read-alouds, students were encouraged to ask questions, negotiate meaning, and 'voice questions, concerns, and resistance to embedded racial and cultural assumptions' (p. 247) to surface racial assumptions and to counter them in 'developmentally and linguistically appropriate ways for young bilinguals' (p. 247). Michael-Luna articulated a compelling argument about the importance of racially and ethnically relevant curricula, critical engagement in literacy learning, and support of students' deep and nuanced analysis of the racial and cultural texts that surround them in schools. Similarly, the teacher in Roy's (2016) case study of an elementary EL classroom with Somali Bantu refugee children in the United States legitimized the examination of ideologies and identities in the classroom by having students draw on their knowledge and experiences to both strengthen their English language, critical thinking, and questioning skills and by sharing her own lived experiences without centering her own experiences in the discussions. What resulted was a better understanding of the students' acculturation process and that of their families.

Broadening contextual understandings of racism, linguicism, and discrimination. In other studies, race-conscious or anti-racist pedagogies supported student identity development, broader contextual understandings of racism, linguicism, and discrimination, and ways to challenge these inequities. This work highlights inquiry-based activities that focus on localized issues and peoples, such as the pedagogical activities designed to introduce alternative discourses around Indigenous peoples and to give students critical tools to examine and challenge societal inequity in Sterzuk and Hengen's (2019) study of Canadian university ESL students. In her qualitative practitioner study of the experiences of 30 immigrant ESL high school students in a three-day Freirian-styled, antidiscrimination leadership program in Canada, Taylor (2006) found that integrative antiracism education could help immigrant students develop a deeper understanding of discrimination and question forms of discrimination previously thought to be 'natural' or unique. The integrative antiracism approach gave students an analytical framework through which to analyze examples of discrimination from their own personal experience and through which to understand discrimination and racialized power dynamics more broadly. Hammond (2006) found similar effects in her critical discourse analysis of a simulated racial inequality exercise, an instructional activity, in a Japanese EFL classroom. In this exercise, students participated as members of a marginalized group and a dominant group, examining their feelings and actions as a part of each group. Hammond found that the students' awareness of racism increased overall, but that much of this awareness focused on overt racism and did not address more subtle forms of racism.

One descriptive pedagogical study drew on both CRT and a multiliteracies pedagogy to create opportunities for international students studying at U.S. universities to create opportunities for students to understand, conceptualize, and analyze discrimination, racism, and race-related issues 
(Guerrettaz \& Zahler, 2016). The authors supplemented the core novel they were studying in their class with texts that featured counternarratives, especially from those voices that had been historically marginalized or silenced, to situate students' comprehension and reading of the novel within current and historical contexts of racial relations. Guerrettaz and Zahler found that as a result, students' perceptions of language, race, and social contexts shifted in critical ways. For example, the students' perception of AAVE in the novel as 'bad English' shifted to understanding AAVE 'as a systematic variety of English that is rule-based and linguistically equivalent in value to SAE [Standard American English]' (p. 201), and that 'the prestige of SAE is about power, not inherent value' (p. 201). The students also built empathy for the Black characters in the book, explored and challenged their ideas of Black masculinity, and broadened their understanding of racial violence and injustice.

More recent pedagogical work has focused on developing students' metalinguistic awareness and expanding their linguistic repertoires in their learning and education. In her work, McKinney (2017) aimed to bridge critical sociolinguistic theory with language education by analyzing classroom interaction and day-to-day life in White schools in South Africa with a focus on Whiteness. McKinney emphasized the need for teachers to position racially minoritized students as 'knowers' or 'legitimate learners,' challenging ANGLONORMATIVITY, or the authority of the White English-speaking teacher to reinforce discourses and practices of Whiteness as the invisible norm in the classroom and discourse and the presumption that White English-speaking teachers are the 'bearers of preferred knowledge' (Soudien, 2007, p. 443; cited in McKinney, 2017). Instead, McKinney argued for what she called TRANSFORMATIVE language and literacy pedagogies that repositioned learners from nondominant backgrounds as meaning-makers, and resourceful and legitimate learners so as to interrupt the expectation that the students become proficient in Standard English to the exclusion of all else. This perspective enabled students from nondominant backgrounds to draw upon their full linguistic and multimodal repertoires in their learning. 'Thus the goal of language and literacy education in schools should be to produce ALL students as creative multilingual and multidialectical languagers, critically aware of the relationship between language and power' (McKinney, 2017, p. 139). McKinney gave some examples of this type of pedagogy: teaching critical language awareness in a high school in San Francisco; translanguaging and writing and presenting poems in home languages that required students to draw upon their own knowledge and cultural resources in a Soweto high school in Johannesburg; and developing biliteracy among 10-12-year-olds in rural Eastern Cape, South Africa.

The work on the effects of racialized pedagogies has begun to lay out a roadmap for identifying an explicit engagement with race in language pedagogy. Despite these promising studies, there continues to be a significant gap in research on race and language pedagogy. Given the obvious interconnections between race and language in pedagogy, more research is needed on both the relationship between race and language, and anti-racist pedagogies in language education. Recent studies in educational contexts that do not specifically address second or foreign language teaching provide some promising pedagogical approaches that could be applied to language teaching. For example, in their comparative case study of the implementation of a critical translingual approach in U.S. secondary English classrooms, Seltzer and de los Ríos (2018) showed how two teachers co-constructed critical, culturally and linguistically relevant literacy curricula, demonstrating how a critical translingual approach invites all language-minoritized students to share their diverse language practices and critique dominant language ideologies that identify those practices as deficient. Instruction and curricula created space for students' existing linguistic expertise and awareness and encourage students to think critically about how language is used and can be used against them. This approach created space for students to challenge one teacher to examine her own privilege and develop emergent raciolinguistic literacies. The students' 'sophisticated articulations of their own raciolinguistic awareness' (p. 63) shaped how the teacher structured her curriculum to highlight the students' experiences around race and languaging in the classroom. The second teacher in the same study, on the other hand, evolved an already refined approach to raciolinguistic literacies co-constructing an ethnic studies course with his students that 'created space for students' (and their families') experiences, language practices, and literacies to come to the fore' (p. 70). Through co-creating the curriculum design and critical literacy, students 
were positioned to problematize the pervasive class, racial, and language ideologies that Selzer and de los Ríos perceived to be permeating Latin American communities.

\section{Discussion}

This literature review has brought to light a pressing and urgent need for the international educational community to continue to analyze and to develop a complex understanding of how language teaching and the lives of learners are shaped by the deeply, but invisibly, racialized nature of the terrain we live our lives and practice our pedagogies within. Since the publications by Kubota and Lin (2006) and Curtis and Romney (2006), we have seen an increase in the scope and range of studies that both problematize the workings of race and racism in language teaching and point to hopeful solutions for addressing the effects of racial inequities. We encourage greater attention to be focused at the intersection of race and language teaching and particularly at the level of episteme and ideology in acknowledgment that epistemological racism wreaks the most insidious yet devastating harm on learners (Kubota, 2009). In order to deepen our collective understanding, we call for research to deepen the following areas:

\subsection{An explicit focus on the interconnectedness of race and language teaching}

A bulk of the literature reviewed focused on the racial identities of language learners and language teachers, but the degree to which the relevance of these identities to the research or theorizing in language teaching is explained varies widely, ranging from cursory to complex (Mitchell, 2012). While not always directly addressing language teaching, scholarship that examined the racial identity construction of language learners and teachers as peripheral to language teaching still sheds ample light for language teaching professionals and often gestures toward a greater focus on pedagogy and its connections to race. One powerful example is Bigelow's (2010) Mogadishu on the Mississippi, which describes five years of research within a community of refugees from Somalia now living in Minnesota. This research was not classroom based, but it is deeply relevant to the issues at hand because among the author's primary arguments is the contention that language teaching is mediated by students' identities and by the conditions of their learning which are not racially neutral. In the case of Bigelow's participants, these conditions included, for instance, war, poverty, trauma, racial profiling, 'racialized xenophobia,' interrupted schooling, and Islamphobia. Bigelow's descriptions make clear the need for educators to be conscious of the relevance of learners' racial identities in language teaching.

In another example, Bucholz (2011) described high school students' negotiations and inhabitations of racial categories through a range of social practices, including language performances. Her ethnography did take place in schools, but it too did not focus on teaching in the conventional sense. When studies did mention language pedagogy and language teacher or student identity, it was often in the form of 'implications' that arise not from examples of practice observed, but from the researcher's recommended alternative suggestions. One such example was Talmy's (2010) study of race and language learner identity in a Hawaiian high school, which critiqued the classroom practices observed and then made recommendations for alternative practices, such as such as activities that 'pose problems' (Freire, 1993) about race and the intersection of racism and linguicism, turn to multiliteracies resources, and develop students' own critical literacy skills. Effective anti-racist language teaching is indeed taking place. For a variety of reasons, including the unwieldiness, labor-intensiveness, and elusiveness of funding for this type of research, documented examples of effective anti-racist practice are simply not being disseminated adequately through journal articles and similar publications. Furthermore, much of the work on racial identities of language teachers and students illuminates in helpful ways the often-invisible shaping of the profession by racial ideologies but does not make close and specific connections to teaching (e.g. Rivers and Ross 2013a,b). What is needed is more deeply pedagogically informed, classroom-based research that clearly demonstrates the connections among teacher identity, race, and language teaching. 
While there is a substantial body of literature that addresses race and education (e.g. Ladson-Billings \& Tate, 1995; Leonardo, 2009; Thomas, 2015), much of the literature on language pedagogy either called for the addressing of race/racism explicitly (e.g. Jorge, 2012) or focused on culturally responsive or critical pedagogy (e.g. Hones, 2007), which implies a lens on race without specifically mentioning race explicitly. Drawing upon the robust literature on race, language, teaching, and education from research in general education classrooms and contexts to help guide research and construct knowledge and understandings more specific to race, racism, language teaching, and language teaching settings could be potentially fruitful.

\subsection{A willingness to see and name race}

For many centuries, systems of erasure have operated around race. Throughout the literature reviewed, many studies of language teaching examined concepts that served as proxies for race, such as cultural mismatch (Kleyn, 2010), language, and culture. While instructive, the explicit naming of these constructs as euphemisms for race is rarely called out and addressed (cf. Lee, 2015). When it Is mentioned, much of the existing literature includes race as one of a 'list' that includes factors such as socioeconomic status, ethnicity, gender, and sexuality. Many of the studies in this literature review sought to examine the influence of multiple social categories, with race listed among them, but race was often not named specifically or analyzed deeply in the studies' analyses.

\subsection{An engagement with the balance between focusing on race and employing an intersectional lens}

As we worked, we followed in the footsteps of a body of literature that attempted to examine the workings of race somewhat apart from the intersectional axes with which the construct is intertwined. It might be argued that shining a light specifically on race allows us to more clearly see the consequences for language teaching. However, the deeper we moved into the literature, the more aware we became that to do so is to adopt a limited and reductionist perspective. It would be more desirable to conceptualize race in the context of its relationality with gender, sexuality, nationality, religion, and other layers of identity, but academic practices have the effect of coercing us toward brevity, oversimplification, and single lenses. One challenge is balancing the naming and maintenance of 'race' as a central focus against an exploration of how race and other categories such as social class, gender, sexual orientation, and religion, influence each other and operate together in language teaching. The complicated crossroads of race and language offer a fertile space for exploring the multilayered intersectionality of these identities. Therefore, given that race intersects in complex ways with other social and identity markers, research in language teaching must address a gap in understanding how this intersectionality explicitly operates in language teaching (Crump, 2014). Romero (2017) argues for moving away from a variable-by-variable approach, which would have us focus on one facet of identity at a time, noting that such a perspective limits our ability to engage with 'diversified identities and identification practices' (p. 325). Rather she suggests that we embrace a variable-with-variable or intersectional approach. To do this, she proposes a focus on the 'decenter,' the moments that take place around the metaphorical edges of our classrooms.

For Kubota (2015), a focus on intersectionality in language teaching is a central focus in anti-racist language education. She suggests that more attention be paid to de-essentializing racism; that is, decentering racism to focus more on the interrelationship between racism and other positionalities such as economic privilege. She also draws our attention to multifaceted forms of racism, decolonizing antiracism by illuminating the power relation between indigenous people and settlers of color in settler colonialism, and making issues of racial inequalities explicit. In other words, understanding the role of racism in broader relations of power in language teaching is of paramount importance.

\subsection{A deep theorization of the interconnectedness of language ideology and racial ideologies}

McKinney (2017) cautions us about the power of language ideology to shape schooling: 'Understanding language ideologies is at the heart of understanding the relationship between language 
and power in schooling. It is the language ideologies underpinning current language policies, curricula, and teacher education and classroom practice that need to be changed if we are to change what counts as language and as legitimate language use in schooling' (p. 161). While studies of race and education abound more generally, language teaching is underexplored. What is missing from much of the literature is a more extensive and deeper examination of the patterns of racial epistemology that shape all that happens in language classrooms, such as classroom routines, how teachers and students interact with and enter into relation with each other, and how decisions about language policy, such as the medium of instruction, are decided. More recently, scholars have begun to explicitly name the interconnectedness of race and language ideologies and in what ways this relationship profoundly affects how students engage with their own identities and their language learning, how teachers engage with their own identities and their language pedagogy, and the contexts within which this work takes place.

Developing raciolinguistic frameworks. Much of the current literature involving race and language teaching relies heavily on CRT to analyze educational opportunities (or lack thereof) for bilingual and multilingual learners, how these learners act and interact within language classrooms, and the conditions under which language teaching occurs and race is addressed (or not). Crump (2014), for example, attempts to address both the fluidity of race and language and identify a theoretical and analytical framework that addresses the ways in which race, racism, and racialization intersect with issues of language, belonging, and identity. Drawing from CRT, Crump names this framework 'LangCrit,' or 'Critical Language and Race Theory.' She describes the LangCrit framework as 'a lens that allows for an examination of how individual social practices and identity performances are connected to a larger ecosocial system of discourses, policies, and practices' (p. 219). This framework 'challenges fixed assumptions related to categories such as language, identity, and race and argues that these categories are socially and locally constructed' while at the same time recognizing that 'fixity plays a role in shaping identity possibilities, in setting the tone for becoming,' accounting for 'a continuum of possibilities for understanding language, race, and identity' (p. 220). While LangCrit focuses on identity, theoretical and analytical frameworks need to be developed in other areas of language teaching that could reveal important insights regarding race and language in language teaching.

In general, however, many of the studies we reviewed could benefit from more robust conceptual/ theoretical frameworks to guide explicit work on race and racism in language teaching. One promising area of research to more explicitly examine the role of race and racism in language teaching is the raciolinguistics (Alim et al., 2016) and raciolinguistic ideologies (Flores \& Rosa, 2015) work that makes explicit connections between language and race. Much of the current literature on raciolinguistics and language teaching work comes from the literature on the teaching of AAVE. Using a RACIOLINGUISTICS framework in examining race and language teaching is particularly useful as it codifies the tight association between race and language and its implications for not only how students of color are perceived but how they are taught and what educational opportunities are available to them. According to Alim (2016), raciolinguistics 'analyz[es] language and race together rather than as discrete and unconnected social processes and employing the diverse methods of linguistics to raise critical questions about the relations between language, race, and power' (p. 5).

Relatively recent research has begun to grow quickly in the area of language teaching, with raciolinguistics work ranging from work in AAVE and education to work in second language teaching (e.g. Flores \& Rosa, 2015). The main focus has been on naming raciolinguistic ideologies that 'conflate certain racialized persons with linguistic deficiency irrespective of their empirical linguistic practices. That is, raciolinguistic ideologies produce racialized language users who are constructed as linguistically deviant even when engaging in linguistic practices positioned as normative or innovative when produced by privileged White language users' (Rosa \& Flores, 2017, p. 177). Flores and Rosa (2015), for example, explored the ways that raciolinguistic ideologies affect the education of long-term English learners, heritage language learners, and Standard English learners. These scholars challenge what they call 'appropriateness-based models of language education' ( p. 154), where some language is seen as 'more appropriate' in specific contexts. Flores and Rosa argued that appropriateness-based 
models of language education have the effect of marginalizing linguistic practices of languageminoritized communities while falsely assuming that modifying already racialized students' language use will eliminate racial hierarchies. The authors argue for racial hierarchies to be at the center of analysis instead of individual practices, and that language pedagogy should confront these racial hierarchies to dismantle it. They suggest, for example, that a 'heteroglossic perspective with critical language awareness opens up space for unmasking the racism inherent in dominant approaches to language education' (p. 154).

\subsection{Attention to practices that decenter Whiteness}

A large portion of the scholarship, focused on standard language ideology, the 'ideal' native speaker, and the White hegemony of English, shows how our current epistemology, the content and ways in which we teach, are currently steeped in White supremacy. Examples of language teaching practice that challenge White supremacy, however, were scant. The knowledge base and research on pedagogies and strategies that continue to help students (and language teachers) move forward in challenging racial hierarchies and address raciolinguistic issues in language teaching and learning needs to grow. Within schools, educators, policy makers, and curriculum developers have power to interrogate texts and practices and support students' deconstructions of the racial discourses and telegraphing that surround them. They can choose to open up identity options for students, encourage their critical questioning, and highlight the racialized nature of the scripts that play themselves out within school walls and across society.

Although examples of language teaching practice that decenter Whiteness were scarce in the research literature, practical resources that support practitioners in decentering Whiteness offer different approaches, pedagogies, and strategies. One helpful example is Houghton, Furumura, Lebedko, and Li's (2013) volume on critical cultural awareness in language education. Rethinking Schools, a nonprofit organization committed to developing and disseminating resources and teaching ideas for anti-racist education, strives to 'balance classroom practice and educational theory' (www.rethinkingschools.org). Faust (2016) includes several strategies/activities to help teachers recognize and address their own privilege in ELT, such as the Identity Circle, Insider/Outsider, and the Overcoming Barriers Chart. She also suggests activities to engage in privilege and ELT work such as courageous conversations and 'Where I'm From' poems. These practical resources may help guide the research in developing epistemological and pedagogical frameworks that address race and language teaching specifically through instructional practice and what is done in classrooms.

\subsection{A more expansive range of antiracist and decolonizing methodologies}

A broader range of methodologies is needed if we are to have an adequately expansive picture of race and language teaching. More studies that examine community engaged projects, public-facing efforts, and teacher- or community-instigated scholarship would be informative. Most of the reviewed studies relied on case study methodology allowing detailed looks at how race operated in particular school, school district, or national contexts. A broader perspective allowing trends, patterns, and unique differences to be examined across cases and contexts could be instructive. In addition, much of the data consists of interviews or teachers' or students' reflections on their racial and linguistic identities and self-reported teacher and student accounts, which are shaped by the context of sharing their accounts as well as their relationship with the interlocutor. A wider range of data, such as observational data, might offer a richer picture of what race and language teaching look like as they come together in classrooms. Case studies that include deep dives into exemplar classrooms and/or schools are especially needed as these honor educators' practice as a site of knowledge construction.

Alongside methodologies that flesh out the intertwined nature of race and language teaching more deeply, other studies could examine How issues of race and language teaching are or could be 
addressed in productive ways in schools and classrooms. Expanding the practice of research-practice partnerships (Coburn \& Penuel, 2016) between university researchers, schools and districts, and communities focused on race, educational equity, and language teaching, could provide important infrastructure for both identifying educational inequities rooted in systemic racism and linguicism and collaboratively designing and shaping changes in instruction, programs, and structures. Researchers in research-practice partnerships can study these processes of systemic and instructional change and how students experience and learn as a result of these collaborative designs. Research from the partnerships can, in turn, be used as evidence for a rationale for equity-oriented reforms (Coburn \& Penuel, 2016).

\subsection{Expansive knowledge construction that moves away from epistemologies of the Global North and Whiteness}

The body of literature is shaped by the geopolitics of academic publishing (Canagarajah, 2002; Curry \& Lillis, 2018) and begs questions about the epistemological possibilities that might be opened up by an orientation away from an exclusive focus on English and Whiteness and toward indigeneity and the Global South. The set of questions under this heading led us to more self-questioning about our role in the academy than any of the others. Much of the literature in English focused only on teaching English. While literature about language variation in languages other than English exists (e.g., Baker \& Smith, 2010; Shenk, 2014; Detey, Durand, Laks, \& Lyche, 2016), we found none that explicitly addressed both race and language teaching, although we believe that the field would benefit greatly from further research and theorization in this area. Most of the prestigious and widely circulated journals in many fields, including language teaching, are published in English and represent research carried out in the Global North, indicating the importance of recognizing the subjugation of Southern theory (Connell, 2007) and knowledge produced in the Global South.

This theme raises questions about the boundaries of academic work as we move forward into a space that challenges monolingual ideologies. We found ourselves asking what responsibility we as authors have to explore work beyond our individual language resources, now that we are practicing in a contemporary context of multilingualism, in a world that assumes multilingual identities and resources.

\section{Conclusion}

The literature we have reviewed holds great promise for advancing our understanding of race in language teaching and addressing educational inequities. Future research should further our understanding of how race operates in language teaching in multiple contexts, along with anti-racist pedagogies, approaches, and decision-making to continue to move towards raciolinguistic equity in language education. Finally, our literature review revealed many areas that warrant their own state-of-the-art pieces. For example, one suggestion is an article that engages with challenges facing educators teaching for indigenous language revitalization as part of a decolonizing project. A second suggestion is one that critically reviews and considers the historical literature on the teaching of Black Englishes or AAVE within a current context of intensified anti-Black racism and \#BlackLivesMatter. Third, we suggest a review of the literature situated at the intersection of race and the teaching of heritage languages.

\section{Questions arising}

1. How language is conceptualized involves deep, consequential, epistemological revisioning of the work of language teaching. How might the nature of both language and race be re-conceptualized to highlight their fluidity and embeddedness in power relations, and what are the implications for language teaching?

2. What does the relationship between race and language teaching look like in a wider range of contexts, such as foreign language education, the teaching of dominant languages other than English, the teaching of less commonly taught languages? 
3. How does the construction of race in language teaching become part of a White settler colonial project, and how can language specialists undo this damage?

4. How does knowledge about race and language teaching get constructed, legitimated, and disseminated so that educators can both understand the roots of educational inequity in schools and classrooms and respond agentively to address these inequities?

5. As we examine the promise held by research in race and language teaching, how can we cultivate richer relationships among policy, research, and practice?

6. How can our epistemological systems be revisioned so that the intersection of race and language teaching is better grounded in Southern theory, indigenous knowledge, and other historically suppressed epistemologies?

7. How can we situate our understandings of race as it relates to language teaching unequivocally within complex intersectional ontologies?

8. How might institutions make commitments to anti-racist language teaching, and what does anti-racist teaching look like, particularly as part of something larger than instructional practice?

9. How can institutions be reshaped so that in-service and preservice educators and administrators are more centrally located in efforts to challenge White supremacy and anti-racist practice?

10. How can we better understand the connections between anti-racist practice and dismantling White supremacy?

\section{References}

Ajayi, L. (2011). Exploring how ESL teachers related their ethnic and social backgrounds to practice. Race, Ethnicity, and Education, 14(2), 253-275.

Alim, H. S. (2010). Critical language awareness. In N. H. Hornberger \& S. L. McKay (Eds.), Sociolinguistics and language education: New perspectives on language and education (pp. 205-231). Bristol, UK: Multilingual Matters.

Alim, H. S. (2016). Introducing raciolinguistics: Racing language and languaging race in hyperracial times. In H. S. Alim, J. R. Rickford, \& A. F. Ball (Eds.), Raciolinguistics: How language shapes our ideas about race. New York, NY: Oxford University Press.

Alim, H. S., \& Baugh, J. (2007). Talkin Black talk: Language, education, and social change. New York, NY: Teachers College Press.

Alim, H. S., Rickford, J. R., \& Ball, A. F. (2016). Raciolinguistics: How language shapes our ideas about race. New York, NY: Oxford University Press.

Álvarez, Z., Calvete, M., \& Sarasa, M. C. (2012). Integrating critical pedagogy theory and practice: Classroom experiences in Argentinean EFL teacher education. Journal for Educators, Teachers and Trainers, 3, 60-70.

Amin, N. (1997). Race and the identity of the nonnative ESL teacher. TESOL Quarterly, 31(3), 580-583.

An, S. (2017). Teaching race through AsianCrit-informed counterstories of school segregation. Social Studies Research and Practice, 12(2), 210-231.

Anya, U. (2017). Racialized identities in second language learning: Speaking blackness in Brazil. New York, NY: Routledge.

Arnaut, K., Blommaert, J., Rampton, B., \& Spotti, M. (2016). Language and superdiversity. New York NY: Routledge.

Austin, T. (2009a). Linguicism and race in the United States: Impact on teacher education from past to present. In R. Kubota, \& A. M. Y. Lin (Eds.), Race, culture, and identities in second language education: Exploring critically engaged practice. New York, NY: Routledge.

Austin, T. (2009b). Conflicting discourses in language teacher education: Reclaiming voice in the struggle. Educational Foundations, 23(3-4), 41-60.

Baker, W., \& Smith, L. C. (2010). The impact of L2 dialect on learning French vowels: Native English speakers learning Québécois and European French. The Canadian Modern Language Review/La revue canadienne des langues vivantes, 66(5), 711-738.

Baugh, J. (2006). Teaching English among linguistically diverse students. In J. Brutt-Griffler \& C. E. Davies (Eds.), English and ethnicity. New York, NY: Palgrave Macmillan.

Bhabha, H. K. (1994). The location of culture. New York, NY: Routledge.

Bhopal, K., \& Preston, J. (2012). Intersectionality and 'race' in education. New York, NY: Routledge.

Bigelow, M. (2010). Mogadishu on the Mississippi: Language, racialized identity, and education in a new land. Malden, MA: Blackwell Publishing.

Block, D. (2010). Globalization and language teaching. In N. Coupland (Ed.), The handbook of language and globalization (pp. 287-304). Oxford, UK: Wiley-Blackwell.

Blommaert, J., \& Rampton, B. (2016). Language and superdiversity. In K. Arnaut, J. Blommaert, B. Rampton, \& M. Spotti (Eds.), Language and superdiversity (pp. 21-48). New York, NY: Routledge.

Boal, A. (1995). The rainbow of desire: The Boal method of theatre and therapy. London, UK: Routledge.

Boal, A. (2002). Games for actors and non-actors (2nd ed.). London, UK: Routledge. 
Bonilla-Silva, E. (2014). Racism without racists, color-blind racism and the persistence of racial inequality in America (4th ed.). Lanham, MD: Rowman \& Littlefield Publishers.

Brayboy, B. (2005). Toward a tribal critical race theory in education. The Urban Review, 37(5), 425-446.

Bucholtz, M. (2011). White kids: Language, race, and styles of youth identity. Cambridge, UK: Cambridge University Press.

Canagarajah, A. (2013). Translingual practice global Englishes and cosmopolitan relations. London, UK/New York, NY: Routledge.

Canagarajah, A. S. (2002). A geopolitics of academic writing. Pittsburgh, PA: University of Pittsburgh Press.

Canagarajah, S. (2016). Multilingual identity in teaching multilingual writing. In G. Barkhuizen (Ed.), Reflections on language teacher identity research. New York, NY: Routledge.

Canessa, A. (2007). Reproducing racism: Schooling and race in highland Bolivia. Race Ethnicity and Education, 7(2), $185-204$.

Castillo-Carsow, ÚM. (2012). The legacy of Gloria Anzaldúa: Finding a place for women of color in academia. Bilingual Review, 31(1), 3-11.

Cervantes-Soon, C. G., Dorner, L., Palmer, D., Heiman, D., Schwerdtfeger, R., \& Choi, J. (2017). Combating inequalities in two-way language immersion programs: Toward critical consciousness in bilingual education spaces. Review of Research in Education, 41, 403-427.

Chacón, C. (2009). Transforming the curriculum of NNESTs: Introducing critical language awareness (CLA) in a teacher education program. In R. Kubota \& A. M. Y. Lin (Eds.), Race, culture, and identities in second language education: Exploring critically engaged practice. New York, NY: Routledge.

Cho, H. (2017). Racism and linguicism: Engaging language minority pre-service teachers in counter-storytelling. Race Ethnicity and Education, 20(5), 666-680.

Coburn, C. E., \& Penuel, W. R. (2016). Research-practice partnerships in education: Outcomes, dynamics, and open questions. Educational Researcher, 45(1), 48-54.

Collins, J. (2017). Dilemmas of race, register, and inequality in South Africa. Language in Society, 46, 39-56.

Connell, R. (2007). Southern theory: The global dynamics of knowledge in social science. Cambridge, MA: Polity Books.

Crump, A. (2014). Introducing LangCrit: Critical language and race theory. Critical Inquiry in Language Studies, 11(3), 207224.

Curry, M. J., \& Lillis, T. (2018). Global academic publishing: Policies, perspectives and pedagogies. Bristol, UK: Multilingual Matters.

Curtis, A., \& Romney, M. (2006). Color, race, and English language teaching: Shades of meaning. Mahwah, NJ: Lawrence Erlbaum.

de Jesus Ferreira, A. (2007). What has race/ethnicity got to do with EFL teaching? Linguagem \& Ensino, 10(1), 211-233.

Detey, S., Durand, J., Laks, B., \& Lyche, C. (2016). Varieties of spoken French. Oxford, UK: Oxford University Press.

Du Bois, W. E. B. (1903/1961). The souls of Black folk. Greenwich, CT: Fawcett Publications. (Originally published 1903, Chicago, IL: A.C. McClurg).

Endo, R. (2016). Counternarrating racialized expectations at school: The diverse enactments of 'non-dominant' identities among 1.5-generation Japanese immigrant youth. Journal of Language, Identity, and Education, 15(4), 201-215.

Farr, M., Seloni, L., \& Song, J. (2010). Ethnolinguistic diversity and education: language, literacy, and culture. New York, NY: Routledge.

Fasold, R. W., \& Shuy, R. W. (1970). Teaching standard English in the inner city. Washington, DC: Center for Applied Linguistics.

Faust, H. (2016). Understanding privilege: Considerations for teaching and teacher training towards social justice. In C. Hastings \& L. Jacobs (Eds.), Social justice in English language teaching. Alexandria, VA: TESOL Press.

Ferguson, A. M. (1982). A case for teaching standard English to black students. English Journal, 71(3), 38-40.

Fitzgerald, K. J. (2017). Recognizing race and ethnicity: Power, privilege, and inequality (2nd ed.). Boulder, CO: Westview Press.

Flores, N. (2013). The unexamined relationship between neoliberalism and plurilingualism: A cautionary tale. TESOL Quarterly, 47(3), 500-520. Retrieved from www.jstor.org/stable/43268031

Flores, N., \& Lewis, M. (2016). From truncated to sociopolitical emergence: A critique of super-diversity in sociolinguistics. International Journal of the Sociology of Language, 241, 97-124.

Flores, N., \& Rosa, J. (2015). Undoing appropriateness: Raciolinguistic ideologies and language diversity in education. Harvard Educational Review, 85(2), 149-171.

Frankenberg, R. (1993). White women, race matters: The social construction of whiteness. Minneapolis, MN: University of Minnesota Press.

Fránquiz, M. E., \& Ortiz, A. A. (2017). Co-editors' introduction: The relationship between race and language in the 21st century. Bilingual Research Journal, 40(4), 335-338.

Freire, P. (1993). Pedagogy of the oppressed. New York, NY: Continuum.

Fujimoto, D. (2006). Stories through perceptual frames. In A. Curtis \& M. Romney (Eds.), Color, race, and English language teaching: Shades of meaning. New York, NY: Lawrence Erlbaum.

García, O., \& Wei, L. (2014). Translanguaging: Language, bilingualism and education. London, UK: Palgrave Macmillan. 
García-Sanchez, I. (2016). Multiculturalism and its discontents: Essentializing ethnic Moroccan and Roma identities in classroom discourse in Spain. In H. S. Alim, J. R. Rickford, \& A. F. Ball (Eds.), Raciolinguistics: How language shapes our ideas about race (pp. 517-533). New York, NY: Oxford University Press.

Glenn, E. N. (2015). Settler colonialism as structure: A framework for comparative studies of U.S. race and gender formation. Sociology of Race and Ethnicity, 1(1), 52-72.

Golombek, P., \& Jordan, S. R. (2005). Becoming 'Black lambs' not 'parrots': A poststructuralist orientation to intelligibility and identity. TESOL Quarterly, 39(3), 513-534.

Grant, R., \& Lee, I. (2009). The ideal English speaker: A juxtaposition of globalization and language policy in South Korea and racialized language attitudes in the United States. In R. Kubota \& A. Lin (Eds.), Race, culture, and identities in second language education: Exploring critically engaged practice. New York, NY: Routledge.

Guerrettaz, A. M., \& Zahler, T. (2016). Black lives matter in TESOL: De-silencing race in a second language academic literacy course. TESOL Quarterly, 51(1), 193-207.

Hammond, K. (2006). More than a game: A critical discourse analysis of a racial inequality exercise in Japan. TESOL Quarterly, 40(3), 545-571.

Haque, E., \& Morgan, B. (2009). Un/marked pedagogies: A dialogue on race in EFL and ESL settings. In R. Kubota \& A. M. Y. Lin (Eds.), Race, culture, and identities in second language education: Exploring critically engaged practice. New York, NY: Routledge.

Harklau, L. (2009). Heritage speakers' experiences in new Latino diaspora Spanish classrooms. Critical Inquiry in Language Studies, 6, 211-242.

Harpalani, V. (2013). Desicrit: Theorizing the racial ambiguity of South Asian Americans. New York University Annual Survey of American Law, 69(1), 77-183.

Hones, D. F. (2007). 'A meeting place for us': Milpera, a newcomer high school. Multicultural Education, 14(4), 8-15.

Houghton, S., Furumura, Y., Lebedko, M., \& Li, S. (Eds.). (2013). Critical cultural awareness: Managing stereotypes through intercultural (language) education. Newcastle upon Tyne, UK: Cambridge Scholars Publishing.

Ibrahim, A. (1999). Becoming Black: Rap and hip hop, race, gender, identity and the politics of ESL learning. TESOL Quarterly, 33(3), 349-369.

Jenks, C. J. (2017). Race and ethnicity in English language teaching: Korea in focus. Bristol, UK: Multilingual Matters.

Jeon, M. (2010). Korean language and ethnicity in the United States: Views from within and across. The Modern Language Journal, 94(1), 43-55.

Jorge, M. (2012). Critical literacy, foreign language teaching and the education about race relations in Brazil. The Latin Americanist/SECOLAS Annals, 56(4), 79-90.

Juárez, B. G. (2008). The politics of race in two languages: An empirical qualitative study. Race, Ethnicity and Education, 11(3), 231-249.

Kachru, B. B. (1992). World Englishes: Approaches, issues and resources. Language Teaching, 25(1), 1-14.

Keengwe, J. (2017). Handbook of research on promoting cross-cultural competence and social justice in teacher education. Hershey, PA: IGI Global.

Kleyn, T. (2010). Cultural mismatch in Honduran Garifuna communities: The role of culture, race, and language in schools. Diaspora, Indigenous, and Minority Education, 4(4), 217-234.

Kramsch, C. (2014). Teaching foreign languages in an era of globalization: Introduction. The Modern Language Journal, 98(1), 296-311.

Kubota, R. (2009). Rethinking the superiority of the native speaker: Toward a relational understanding of power. In N M. Doerr (Ed.), The native speaker concept: Ethnographic investigations of native speaker (pp. 233-247). Berlin, Germany: Mouton de Gruyter.

Kubota, R. (2013). Critical explorations of multiculturalism and race: Language teachers reflecting on public events in the news. In C. J. Figueredo \& M. R. Mastrella-de-Andrade (Eds.), Ensino de línguas na contemporaneidade: Práticas de construção de identidades [Identity practices in language learning and teaching contexts] (pp. 129-149). Campinas, Brazil: Pontes Editora.

Kubota, R. (2015). Race and language learning in multicultural Canada: Toward critical antiracism. Journal of Multilingual and Multicultural Development, 36, 3-12.

Kubota, R. (2016). The multi/plural turn, postcolonial theory, and neoliberal multiculturalism: Complicities and implications for applied linguistics. Applied Linguistics, 37(4), 474-494.

Kubota, R. (2019). Confronting epistemological racism, decolonizing scholarly knowledge: Race and gender in applied linguistics. Applied Linguistics, 1-22.

Kubota, R., \& Catlett, S. (2008). Spanish only for foreign language in the elementary school (FLES): Competing discourses in local language policy. Foreign Language Annals, 41(1), 102-118.

Kubota, R., \& Lin, A. (2006). Race and TESOL: Introduction to concepts and theories. TESOL Quarterly, 40(3), 471-493.

Kubota, R., \& Lin, A. (2009). Race, culture, and identities in second language education: Exploring critically engaged practice. New York, NY: Routledge. 
Ladson-Billings, G., \& Tate, W. F., IV. (1995). Toward a critical race theory of education. Teachers College Record, 97(1), 47-68.

Lee, E. (2015). Doing culture, doing race: Everyday discourses of 'culture' and 'cultural difference' in the English as a second language classroom. Journal of Multilingual and Multicultural Development, 36, 80-93.

Lee, E., \& Simon-Maeda, A. (2006). Racialized research identities in ESL/EFL research. TESOL Quarterly, 40(3), 573-594.

Leonardo, Z. (2009). Race, whiteness, and education. New York, NY: Routledge.

Li, G., \& Beckett, G. H. (2011). 'Strangers' of the academy: Asian women scholars in higher education. Sterling, VA: Stylus Publishing.

Liggett, T. (2008). Frames of reference: The impact of race on teaching strategy and classroom discussion. Urban Review, 40, 386-402.

Liggett, T. (2009). Unpacking White racial identity in English language teacher education. In R. Kubota \& A. M. Y. Lin (Eds.), Race, culture, and identities in second language education: Exploring critically engaged practice. New York, NY: Routledge.

Liggett, T. (2014). The mapping of a framework: Critical race theory and TESOL. Urban Review, 46, 112-124.

Lin, A. (2006). From learning English in a colony to working as a female TESOL professional of color: A personal odyssey. In A. Curtis \& M. Romney (Eds.), Color, race, and English language teaching: Shades of meaning. New York, NY: Lawrence Erlbaum.

Lin, A., Grant, R., Kubota, R., Motha, S., Tinker Sachs, G., Vandrick, S., \& Wong, S. (2004). Women faculty of color in TESOL: Theorizing our lived experiences. TESOL Quarterly, 38(3), 487-504.

Lin, A., \& Motha, S. (2019). Reconstituting desire in TESOL: Collectivity and empire. In R. Arber \& M. Weinmann (Eds.), Rethinking languages education: Directions, challenges and innovations. New York, NY: Routledge.

Lin, S. C. (1965). Pattern practice in the teaching of standard English to students with a non-standard dialect. New York, NY: Teachers College.

Lippi-Green, R. (2006). English with an accent: Language, ideology, and discrimination in the United States. New York, NY: Routledge.

Lippi-Green, R. (2012). English with an accent: Language, ideology, and discrimination in the United States (2nd ed.). New York, NY: Routledge.

Liu, P. E., \& Tannacito, D. J. (2013). Resistance by L2 writers: The role of racial and language ideology in imagined community and identity investment. Journal of Second Language Writing, 22, 355-373.

López-Gopar, M., Clemente, A., \& Sughrua, W. (2011). Co-creating identities through identity texts and dialogical ethnography. Writing \& Pedagogy, 3(2), 241-264.

Luke, A., \& Lin, A. (2006). Coloniality, postcoloniality, and TESOL ... Can a spider weave its way out of the web that it is being woven into just as it weaves? Critical Inquiry in Language Studies, 3(2-3), 65-73.

Mackie, A. (2003). Race and desire: Toward critical literacies for ESL. TESL Canada Journal, 20(2), 23-37.

Makoni, S. (2012). A critique of language, languaging, and supervernacular. Muitas Vozes, 1/2, 189-199.

Makoni, S., \& Pennycook, A. D. (2007). Disinventing and reconstituting languages. In S. Makoni \& A. Pennycook (Eds.), Disinventing and reconstituting languages (pp. 1-41). Bristol, UK: Multilingual Matters.

Malsbary, C. (2014). Will this hell never end?": Substantiating and resisting race-language policies in a multilingual high school. Anthropology and Education Quarterly, 45(4), 373-390.

Marx, S. (2006). Revealing the invisible: Confronting passive racism in teacher education. New York, NY: Routledge Press.

Marx, S. (2009). 'It's not them; it's not their fault': Manifestations of racism in the schooling of Latina/os and ELLs. In R. Kubota \& A. M. Y. Lin (Eds.), Race, culture, and identities in second language education: exploring critically engaged practice (pp. 81-98). New York, NY: Routledge.

Marx, S., \& Pray, L. (2011). Living and learning in Mexico: Developing empathy for English language learners through study abroad. Race, Ethnicity, and Education, 14(4), 507-535.

Marx, S., \& Saavedra, C. M. (2014). Understanding the epistemological divide in ESL education: What we learned from a failed university-school district collaboration. Urban Education, 49(4), 418-439.

May, S. (Ed.). (2014). The multilingual turn: Implications for SLA, TESOL and bilingual education. New York, NY/London, UK: Routledge.

McKinney, C. (2017). Language and power in post-colonial schooling: Ideologies in practice (Language, culture, and teaching). New York, NY: Routledge.

Melamed, J. (2011). Represent and destroy: Rationalizing violence in the new racial capitalism. Minneapolis, MN: University of Minnesota Press.

Michael-Luna, S. (2008). Todos somos Blancos/We are all White: Constructing racial identities through texts. Journal of Language, Identity \& Education, 7(3-4), 272-293.

Michael-Luna, S. (2009). Narratives in the wild: Unpacking critical race theory methodology for early childhood bilingual education. In R. Kubota \& A. M. Y. Lin (Eds.), Race, culture, and identities in second language education: Exploring critically engaged practice. New York, NY: Routledge.

Mignolo, W. (2003). The darker side of the Renaissance: Literacy, territoriality, and colonization (2nd ed). Ann Arbor, MI: University of Michigan Press. 
Mitchell, K. (2012). Race, difference, meritocracy, and English: Majoritarian stories in the education of secondary multilingual learners. Race Ethnicity and Education, 16(3), 339-364.

Mohanty, C. (1984). Under Western eyes: Feminist scholarship and colonial discourses. Boundary, 12/13(2), 333-358.

Morgan, B. (2004). Teacher identity as pedagogy: Towards a field-internal conceptualisation in bilingual and second language education. International Journal of Bilingual Education and Bilingualism, 7(2-3), 172-188.

Morita-Mullaney, T. (2018). The intersection of language and race among English learner (EL) leaders in desegregated urban Midwest schools: A LangCrit narrative study. Journal of Language, Identity \& Education, 17(114), 1-17.

Motha, S. (2006a). Racializing ESOL teacher identities in U.S. K-12 public schools. TESOL Quarterly, 40(3), 495-518.

Motha, S. (2006b). Out of the safety zone. In A. Curtis \& M. Romney (Eds.), Color, race, and English language teaching: Shades of meaning. New York, NY: Lawrence Erlbaum.

Motha, S. (2014). Race, empire, and English language teaching. New York, NY: Teachers College Press.

Motha, S. (2016). Who we are: Teacher identity, race, empire, and nativeness. In G. Barkhuizen (Ed.), Reflections on language teacher identity research. New York, NY: Routledge.

Motha, S., Jain, R., \& Tecle, T. (2012). Translinguistic identity-as-pedagogy: Implications for language teacher education. International Journal of Innovation in English Language Teaching and Research, 1, 2156-5716.

Motha, S., \& Lin, A. (2014). Non-coercive rearrangements: Theorizing desire in TESOL. TESOL Quarterly, 48(2), 331-359.

Moya, P. M. L., \& Markus, H. R. (2010). 'Doing race: An introduction.' In H. R. Markus \& P. M. L. Moya (Eds.), Doing race: 21 essays for the 21st century (pp. 1-102). New York, NY: W. W. Norton \& Company.

Müller, U. A. (2011). Far away so close: Race, Whiteness, and German identity. Identities, 18(6), 620-645.

Navarro, J. (2016). WORD: Hip-hop, language, and indigeneity in the Americas. Critical Sociology, 42(4-5), 567-581.

Nero, S. (2006a). An exceptional voice: Working as a TESOL professional of color. In A. Curtis \& \& M. Romney (Eds.), Color, race, and English language teaching: Shades of meaning. New York, NY: Lawrence Erlbaum.

Nero, S. J. (2006b). Dialects, Englishes, creoles, and education. Mahwah, NJ: Lawrence Erlbaum.

Nero, S. J., \& Stevens, L. (2018). Analyzing students' writing in a Jamaican Creole-speaking context: An ecological and systemic functional approach. Linguistics and Education, 43, 13-24.

Orzulak, M. (2015). Disinviting deficit ideologies: Beyond 'that's standard,' 'that's racist,' and 'that's your mother tongue.' Research in the Teaching of English, 50(2), 176-198.

Paperson, L. (2017). A third university is possible. Minneapolis, MN: University of Minnesota Press.

Park, G. (2013). Situating the discourses of privilege and marginalization in the lives of two East Asian women teachers of English. Race, Ethnicity and Education, 18, 108-133.

Pennycook, A. (2001). Critical applied linguistics: A critical introduction. Mahwah, NJ: Lawrence Erlbaum.

Pennycook, A., \& Otsuji, E. (2015). Metrolingualism: Language in the city. London, UK/New York, NY: Routledge.

Phillipson, R. (1992). Linguistic Imperialism. Oxford, UK: Oxford University Press.

Pieterse, J. (1990). Empire \& emancipation: Power and liberation on a world scale. London, UK: Pluto Press.

Pimentel, C. (2011). The color of language: The racialized educational trajectory of an emerging bilingual student. Journal of Latinos and Education, 10(4), 335-353.

Pollock, M. (2004). Colormute: Race talk dilemmas in an American school. Princeton, NJ: Woodstock: Princeton University Press.

Ramirez, J. D. (2005). Ebonics: The urban education debate (2nd ed.). Bristol, UK: Multilingual Matters.

Reyhner, J. A. (2015). Teaching indigenous students: Honoring place, community, and culture. Norman, OK: University of Oklahoma Press.

Rivers, D. J., \& Ross, A. S. (2013a). Idealized English teachers: The implicit influence of race in Japan. Journal of Language, Identity \& Education, 12, 321-339.

Rivers, D. J., \& Ross, A. S. (2013b). Uncovering stereotypes: Intersections of race and English native-speakerhood. In S. A. Houghton, Y. Furumura, M. Lebedko, \& S. Li (Eds.), Critical cultural awareness: Managing stereotypes through intercultural (language) education (pp. 42-61). Newcastle upon Tyne, UK: Cambridge Scholars.

Roediger, D. (2018). Working towards Whiteness: How America's immigrants became White: The strange journey from Ellis Island to the suburbs. New York, NY: Basic Books.

Romero, Y. (2017). Developing an intersectional framework: Engaging the decenter in language studies. Critical Inquiry in Language Studies, 14(4), 320-346.

Rosa, J., \& Flores, N. (2017). Do you hear what I hear? Raciolinguistic ideologies and culturally sustaining pedagogies. In D. Paris \& H. S. Alim (Eds.), Culturally sustaining pedagogies: Teaching and learning for justice in a changing world (pp. 175-190). New York, NY: Teachers College Press.

Ross, E., \& Pang, V. (2006). Race, ethnicity, and education. Westport, CT: Praeger Publishers.

Roy, L. (2016). 'So what's the difference?' Talking about race with refugee children in the English language learner classroom. TESOL Journal, 8(3), 540-563.

Ruecker, T., \& Ives, L. (2014). White native English speakers needed: The rhetorical construction of privilege online teacher recruitment spaces. TESOL Quarterly, 49, 733-756. 
Samimy, K. (2011). Multiple mentors in my career as a university faculty. In G. Li \& H. G. Beckett (Eds.), 'Strangers' of the academy: Asian women scholars in higher education. Sterling, VA: Stylus Publishing.

Saraceni, M. (2015). World Englishes: A critical analysis. London, UK: Bloomsbury Academic.

Seltzer, K., \& de los Ríos, C. V. (2018). Translating theory to practice: Exploring teachers' raciolinguistic literacies in secondary English classrooms. English Education, 51(1), 49-79.

Shenk, E. M. (2014). Teaching sociolinguistic variation in the intermediate language classroom: Voseo in Latin America. Hispania, 97(3), 368-381.

Sherris, A., \& Peyton, J. K. (2019). Teaching writing to children in Indigenous languages: Introduction. In A. Sherris \& J. K. Peyton (Eds.), Teaching writing to children in Indigenous languages: Instructional practices from global contexts (pp. 1-24). New York, NY: Routledge.

Sister Scholars: Grant, R., Kubota, R., Lin, A., Motha, S., Tinker Sachs, G., Vandrick, S., \& Wong, S. (forthcoming). Strategies for sisterhood in the language education academy. Journal of Language, Identity, and Education.

Skutnabb-Kangas, T. (2000). Linguistic genocide in education, or worldwide diversity and human rights? Mahwah, NJ: Lawrence Erlbaum.

Smith, M. (2015). Who is a legitimate French speaker? The Senegalese in Paris and the crossing of linguistic and social borders. French Cultural Studies, 26(3), 317-332.

Smith, M. (2019). Senegal abroad: Linguistic borders, racial formations, and diasporic imaginaries. Madison, WI: The University of Wisconsin Press.

Solorzano, D., \& Bernal, D. (2001). Examining transformational resistance through a critical race and LatCrit theory framework: Chicana and Chicano students in an urban context. Urban Education, 36(3), 308-342.

Soudien, C. (2007). The asymmetries of contact: An assessment of 30 years of school integration in South Africa. Race Ethnicity and Education, 10(4), 439-456.

Stanley, P. (2013). A critical ethnography of 'Westerners' teaching English in China Shanghaied in Shanghai. New York, NY: Routledge.

Sterzuk, A., \& Hengen, S. (2019). 'When I came to Canada like I heard lots of bad stuff about Aboriginal people': Disrupting settler colonial discourses through English language teaching. In M. López Gopar (Ed.), International perspectives on critical pedagogies in ELT (pp. 19-37). Basingstroke, UK: Palgrave MacMillan.

Sung, C. C. M. (2011). Race and native speakers in ELT: parents' perspectives in Hong Kong. English Today, 27(3), 25-29.

Takahashi, K. (2012). Language learning, gender and desire: Japanese women on the move. Bristol, UK: Multilingual Matters.

Talburt, S., \& Stewart, M. A. (1999). What's the subject of study abroad? Race, gender, and 'living culture'. The Modern Language Journal, 83(2), 163-175.

Talmy, S. (2010). Becoming 'local' in ESL: Racism as resource in a Hawai'i public school. Journal of Language, Identity, and Education, 9, 36-57.

Taylor, A. (2017). Putting race on the table: How teachers make sense of the role of race in their practice. Harvard Educational Review, 87(1), 50-73, 157.

Taylor, L. (2006). Wrestling with race: The implications of integrative antiracism education for immigrant ESL youth. TESOL Quarterly, 40(3), 519-544.

Taylor-Mendes, C. (2009). Construction of racial stereotypes in English as a foreign language (EFL) textbooks: Images as discourse. In R. Kubota \& A. Lin (Eds.), Race, culture, and identities in second language education: Exploring critically engaged practice. New York, NY: Routledge.

Thomas, E. E. (2015). 'We always talk about race': Navigating race talk dilemmas in the teaching of literature. Research in the Teaching of English, 50(2), 154-175.

Thomson, C., \& Stakhnevich, J. (2010). Language practices and perceptions: A case study of six South African teachers. Critical Inquiry in Language Studies, 7(4), 270-297.

Tinker Sachs, G. (2006). The world away from home. In A. Curtis \& M. Romney (Eds.), Color, race, and English language teaching: Shades of meaning. New York, NY: Lawrence Erlbaum.

Tuck, E., Mackenzie, M., \& McCoy, K. (2016). Introduction. Land education: Indigenous, post-colonial, and decolonizing perspectives on place and environmental education research. In K. McCoy, E. Tuck, \& M. McKenzie (Eds.), Land education: Rethinking pedagogies of place from indigenous, postcolonial, and decolonizing perspectives. New York, NY: Routledge.

Underriner, J., \& Jansen, J. (2018). The role of institutions of higher education in teaching Indigenous languages: Ichishkíin and Chinuk Wawa. Language and Linguistics Compass, 12(5). doi:10.1111/lnc3.12276

Valdez, V. E., Freire, J. A., \& Delavan, M. G. (2016). The gentrification of dual language education. Urban Review, 48, 601627.

Valverde, K.-L. C., \& Dariotis, W. M. (2020). Fight the tower: Asian American women scholars' resistance and renewal in the academy. Rutgers, NJ: Rutgers University Press.

Varghese, M., Motha, S., Trent, J., Park, G., \& Reeves, J. (2016). Language teacher identity in multilingual education. TESOL Quarterly (SI).

Vitanova, G. (2016). Exploring second-language teachers' identities through multimodal narratives: Gender and race discourses. Critical Inquiry in Language Studies, 13(4), 261-288. 
Wheeler, R. (2016). So much research, so little change: Teaching standard English in African American classrooms. Annual Review of Linguistics, 2(1), 367-390.

Wong, S. (2006). Perpetual foreigners: Can an American be an American? In A. Curtis \& M. Romney (Eds.), Color, race, and English language teaching: Shades of meaning. Mahwah, NJ: Lawrence Erlbaum.

Wong, S., \& Grant, R. (2016). Racializing justice in TESOL: Embracing the burden of double consciousness. In L. Jacobs \& C. Hastings (Eds.), Social justice and English language teaching (pp. 165-176). Charlotte, NC: Information Age Publishing \& TESOL International.

Wooten, J., \& Cahnmann-Taylor, M. (2014). Black, White, and rainbow [of desire]: The colour of race-talk of pre-service world language educators in Boalian theatre workshops. Pedagogies: An International Journal, 9(3), 179-195.

Yamada, M. (2015). The role of English teaching in modern Japan: Diversity and multiculturalism through English language education in a globalized era. New York, NY: Routledge.

Young, A., Barrett, E., Young Rivera, Y., \& Lovejoy, K. B. (2014). Other people's English: Code-meshing, code-switching, and African American literacy. New York, NY: Teachers College Press.

Kerry Soo Von Esch is an Assistant Professor in Educating Culturally and Linguistically Diverse Students at Seattle University. Her research examines teacher learning centered on developing emergent bilingual students' cultural and linguistic repertoires, and school- and classroom-embedded professional development and teacher education focused on sustaining and linguistically responsive pedagogies. Her work has been published in journals such as Journal of Teacher Education, The Elementary School Journal, and AERA Open.

Suhanthie Motha's practice is located on Coast Salish homelands and examines race and empire within ELT. A teacher educator and associate professor at the University of Washington, she is the author of Race, empire, and English language teaching, which won the American Educational Studies Association Critics' Choice Book Award and the Comparative and International Education Society's Globalization and Education SIG's Book Award. Her work has been published in journals including TESOL Quarterly, The Modern Language Journal, Race Ethnicity and Education, Annual Review of Applied Linguistics, Critical Inquiry in Language Studies, Peace and Change, Language Teaching, and in various edited collections.

Ryuko Kubota is a Professor in the Department of Language and Literacy Education at University of British Columbia, where she teaches applied linguistics and teacher education. Her research draws on critical approaches to L2 ducation, focusing on race, gender, culture, and language ideologies. Her publications appear in such journals as Applied Linguistics, Critical Inquiry in Language Studies, Foreign Language Annals, Journal of Multilingual and Multicultural Development, Journal of Second Language Writing, TESOL Quarterly, and World Englishes. She is a co-editor of Race, culture, and identities in second language education: Exploring critically engaged practice (Routledge, 2009).

Cite this article: Von Esch, K. S., Motha, S., \& Kubota, R. (2020). Race and language teaching. Language Teaching, 53(4), 391-421. https://doi.org/10.1017/S0261444820000269 